\title{
Petrologic and stable isotopic studies of a fossil hydrothermal system in ultramafic environment (Chenaillet ophicalcites, Western Alps, France): Processes of carbonate cementation
}

\author{
Romain Lafay ${ }^{\mathrm{a}, *}$, Lukas P. Baumgartner ${ }^{\mathrm{a}}$, Schwartz Stephane ${ }^{\mathrm{b}}$, Picazo Suzanne ${ }^{\mathrm{a}}$, \\ Montes-Hernandez German ${ }^{c}$, Vennemann Torsten ${ }^{\text {d }}$ \\ a Institute of Earth Sciences, University of Lausanne, Géopolis, 1015 Lausanne, Switzerland \\ b Univ. Grenoble Alpes, ISTerre, F-38041 Grenoble, France \\ c CNRS, ISTerre, F-38041 Grenoble, France \\ d Institute of Earth Surface Dynamics, University of Lausanne, Géopolis, 1015 Lausanne, Switzerland
}

\section{A R T I C L E I N F O}

\section{Article history:}

Received 29 December 2016

Accepted 7 October 2017

Available online 14 October 2017

\section{Keywords:}

Ophicalcite

Hydrothermal carbonation

Serpentinization

Stable isotope

Fast cementation

\begin{abstract}
A B S T R A C T
The Late Jurassic Chenaillet ophiolitic complex (Western Alps) represents parts of an oceanic core-complex of the Liguria-Piemonte domain. A model for the origin and evolution of the Chenaillet ophicalcites based on textural and isotopic characterization is presented. The Chenaillet ophicalcites correspond to brecciated serpentinized peridotites that record seafloor shallow serpentinization at a minimum temperatures of $150{ }^{\circ} \mathrm{C}$ followed by authigenic carbonation. Carbonation starts with a network of micrometric to millimetric pre- or syn-clast formation calcite veins accompanied by a pervasive carbonation of residual olivine and serpentine inside the serpentinite mesh core. A matrix of small calcite $(<50 \mu \mathrm{m}, 12 \mu \mathrm{m}$ in average) cemented clasts after their individualization. Texture of the breccia, grain size distribution within the matrix, and chrysotile clusters support rapid cementation from a strongly oversaturated fluid due most likely to hydrothermal fluid cooling and decompression. Later fluids infiltrated by multiple crack formation and some dolomite locally formed along serpentinitecalcite interfaces. Carbonates have $\delta{ }^{13} \mathrm{C}$ (VPDB) values that range between $-5 \%$ and $+0.4 \%$. The lower values were obtained for calcite within the serpentinite clasts. The $\delta^{18} \mathrm{O}$ (VSMOW) values have a range between $+11 \%$ 。 and $+16 \%$ in carbonated clasts. The $\delta^{18} \mathrm{O}$ values in the matrix are fairly homogeneous with an average at $+12 \%$ 。 and the late calcite veins have values between +12.5 and $+15.5 \%$. These values suggest a relatively high temperature of formation for all the carbonates. Carbonates within clast are mainly characterized by a formation temperature in the range of $110{ }^{\circ} \mathrm{C}$ to $180{ }^{\circ} \mathrm{C}$ assuming a $\delta^{18} \mathrm{O}$ value of seawater of $0 \%$, the matrix forms at a temperature of ca. $165^{\circ} \mathrm{C}$. Late veins are characterized by a formation temperature ranging between 120 and $155^{\circ} \mathrm{C}$. We propose a model where serpentinization is followed by discrete carbonation then brecciation and cementation as a consequence of continuous hydrothermal fluid circulation in the serpentinite basement. This is comparable to observations made in the stockwork of present-day long-lived oceanic hydrothermal systems.
\end{abstract}

(C) 2017 Elsevier B.V. All rights reserved.

\section{Introduction}

The non-uniform flow of basaltic melt (Tucholke and Lin, 1994) leads to amagmatic segments of the mid-oceanic ridges. This favors the exhumation of ultramafic rocks on the oceanic seafloor along detachment faults at (ultra)-slow spreading ridges ( $<55 \mathrm{~mm} / \mathrm{yr}$; Mével, 2003; Schroeder et al., 2002). It results in the formation of corrugated megamullions structures, the so-called Oceanic Core Complexes (OCCs, Ildefonse et al., 2007; MacLeod et al., 2009). In this setting, seawater circulation along large transform faults enhances peridotite alteration (Blackman et al., 2002; Cannat et al., 2006; Evans, 2004; McCaig

\footnotetext{
* Corresponding author.

E-mail address: romain.lafay@unil.ch (R. Lafay).
}

et al., 2010). Here, the minerals olivine and pyroxene in peridotite are far from thermodynamic equilibrium and water-rock interaction produces serpentine that represent a major mineralogical component of the oceanic lithosphere. While the serpentinization reactions are common whatever the dynamic setting of the oceanic lithosphere, petrological and geochemical studies have shown that this reaction is favored along detachment faults: first at high temperatures $\left(300-500{ }^{\circ} \mathrm{C}\right)$, often in relation with gabbroic intrusions (Alt et al., 2012; McCaig et al., 2010), but then develops pervasively close to the ocean floor $\left(\sim 20{ }^{\circ} \mathrm{C}\right)$ due to hot marine water circulation activated by heat generated through the exothermic serpentinization reaction itself (Allen and Seyfried, 2004; Früh-Green et al., 2003; Kelley et al., 2001). While serpentinization takes place over a wide range of temperature, the maximum reaction rate for serpentinization reaction is observed around 
250-300 ${ }^{\circ} \mathrm{C}$ (Martin and Fyfe, 1970). The maximum depth for serpentinization can be several kilometers at slow spreading ridges (Cannat et al., 2010). The interaction of seawater with ultramafic rocks results in the development of characteristic mesh textures and veins composed of chrysotile and lizardite (the most abundant varieties of serpentine in hydrothermal environments or low-grade metamorphism; Evans, 2004; Wicks and Whittaker, 1977). Moreover, peridotite hydration is accompanied by incorporation of a large amount of mobile trace elements (e.g. Bonatti et al., 1984; Decitre et al., 2002; Kodolányi et al., 2011; Vils et al., 2008) and the production of $\mathrm{H}_{2}$, which are released into the hydrothermal fluids (Charlou et al., 2002; Evans et al., 2013; Frost, 1985).

The recent underwater observations of the seafloor attest to the diversity of hydrothermal systems in response to the heterogeneity in the oceanic lithosphere i.e. spreading rates, cracking intensity, fluid infiltration depth, and volcanic activity (Andreani et al., 2007; Boschi et al., 2006; McCaig et al., 2010; McCaig and Harris, 2012; Petersen et al., 2009). They reveal that (ultra)mafic rocks might be locally associated with carbonate deposits (Denny et al., 2016; Früh-Green et al., 2003). The presence of carbonated peridotite within serpentinite basement (Bach et al., 2011; Eickmann et al., 2009a, 2009b) or the development of a carbonate chimney (Früh-Green et al., 2003) in hydrothermal systems (e.g. Lost City or Logatchev hydrothermal field,) raised many questions on the link between serpentinization and carbonation reactions, and emphasized the complexity of hydrothermal systems at slow spreading ridges (Kelley et al., 2001; Schrenk et al., 2004). The hydrothermal cell development is intimately linked to dynamics of the oceanic lithosphere and magmatic activity and can either involve sediments, ultramafic rocks or tholeiitic intrusions (Bach et al., 2011; McCaig and Harris, 2012; Mottl, 1983). Carbonates in hydrothermal systems can be formed from different fluids, at ambient seawater temperatures to hydrothermal conditions. The complex fluid behavior in hydrothermal systems can lead to carbonate formation in peridotites either during heating of seawater, cooling of hydrothermal fluid or as a consequence of mixing of the hydrothermal fluid with seawater (Eickmann et al., 2009a, 2009b; Klein et al., 2015) as a response of the evolution of the hydrothermal loops in long lived hydrothermal systems (Bach et al., 2011; Schwarzenbach et al., 2013).

Such rocks were found in several locations within the LiguriaPiemonte relicts (Lemoine, 1980). Different interpretations for the origin of ophicalcites in the Ligura-Piemonte and in other ophiolites have been proposed: (1) the result of mechanical mixing of hydrothermal carbonates and reworked ultramafic rocks as a consequence of tectosedimentary activity during obduction and exhumation (Bernoulli and Weissert, 1985; Bortolotti and Passerini, 1970; Früh-Green et al., 1990; Gianelli and Principi, 1977; Lemoine, 1980), (2) carbonation of oceanic basement due to infiltration of seawater or fluids derived from pelagic sediments (Bernoulli, 1974; Clerc et al., 2014; Demény et al., 2007; Früh-Green et al., 1990; Schwarzenbach et al., 2013; Treves and Harper, 1994; Tucholke et al., 2013), (3) metasomatic reactions related to endogenic alkaline fluids circulation (Trommsdorff et al., 1980) or (4) the result of gas infiltrations related to underlying mantle activity (Bonatti et al., 1974; Haggerty, 1991). Nevertheless, the source of $\mathrm{CO}_{2}$ and $\mathrm{CaO}$ remains debated and they might have different origins, including marine carbonate dissolution, metamorphic or mantel origin, or a combination thereof.

Ophicalcites with various petrological and textural characteristics are found in the upper part of serpentinites in the Chenaillet ophiolite and were interpreted to result from a succession of carbonation events (Lemoine et al., 1987). A detailed petrologic, textural, and geochemical (including $\mathrm{C}$ - and $\mathrm{O}$-isotopic measurements) study of ophicalcite breccias of the Chenaillet (W. Alps, France-Italy border) is presented here. The aim is to delineate the sequence of carbonation and determine the processes leading to the formation of the ophicalcites.

\section{Geological setting, previous work, and sample localities}

The legacy of the Jurassic opening of the Tethys is exposed as mafic-ultramafic units in the Western Alps, including the Chenaillet complex (Fig. 1a) (Bertrand et al., 1982; Caby, 1995; Li et al., 2013). The lithological succession (i.e. basalts, gabbros, and exhumed peridotites) is comparable to those found in the Liguria-Piemonte ophiolites of the Apennine (Barrett and Spooner, 1977; Lagabrielle and Cannat, 1990). The similarity of the lithological sequence observed in the Chenaillet complex with the one recorded at slow spreading Mid Ocean Ridges (MORs) established the Chenaillet unit as an analogue of present day OCCs (Chalot-Prat and Bourlier, 2005; Festa et al., 2015; Lagabrielle et al., 2015; Lagabrielle and Lemoine, 1997; Manatschal et al., 2011). Recent studies on the mantle composition throughout the Alpine Tethys units suggests that the Chenaillet ophiolite belongs to the most oceanward portion of the hyper-extended margin rather than to a true ocean (Picazo et al., 2016; Rampone et al., 1996).

Many of the ophiolitic units from the Alpine belt are affected by high-pressure metamorphism (10-15 Kbar) related to the subduction of the Tethys domain (Dal Piaz and Ernst, 1978; Tricart and Schwartz, 2006). However, the Chenaillet massif records only oceanic prehnite-pumpellyite to amphibolite facies conditions (Mevel et al., 1978), related to sea-floor exhumation. The apatite and zircon fission track analyses performed on plagio-granite reveal that the massif was cooled before $65 \mathrm{Ma}$ (Schwartz et al., 2007) and has escaped the high pressure Alpine metamorphic overprint (Bertrand et al., 1987; Lagabrielle et al., 2015; Lewis and Smewing, 1980; Manatschal et al., 2011). The Chenaillet unit was obducted onto the proximal European margin during the Cretaceous convergence between Europe and Adria (e.g. Lagabrielle, 1987) and has been affected by anchi-facies metamorphism (Goffé et al., 2004). The zircon and apatite fission track ages of 118 and 65 Ma respectively in the Chenaillet unit suggests that the two chronometers have escaped complete resetting(Agard et al., 2002). The unit consists of a thin thrust sheet $(<1 \mathrm{~km})$ overlying the HP-LT units (Schistes lustrés) of the western Alps.

The Chenaillet massif consists of a continuous magmatic series with serpentinized peridotite, small bodies of gabbro with olivine (pseudomorphosed into chlorite), plagioclase (albitized) and accessory clinopyroxene (Chalot-Prat and Bourlier, 2005) crosscut by tholeiitic feeder dykes. The basalts have an E-MORB composition and overlie the exhumed mantle in an up to $400 \mathrm{~m}$ thick series (Bertrand et al., 1987). The lower part of the unit is mostly brecciated.

The cooling of the oceanic lithosphere is related to its exhumation during Jurassic hyper-extension. Oceanic metamorphism and tectonism results in flaser gabbros, metasomatism, and high-temperature, low pressure amphibolite paragenesis (Mevel et al., 1978). Magmatic rocks now sit on ultramafic basement (Lagabrielle and Lemoine, 1997) composed of massive serpentinites, derived mainly from a lherzolitic protolith (Bertrand et al., 1982; Caby, 1995; Chalot-Prat and Bourlier, 2005; Lafay et al., 2013). Dunitic and pyroxenitic domains are present locally, as well as mylonites formed at high-temperature (Manatschal et al., 2011). Serpentinites are mainly characterized by mesh and bastite textures, classical textures for serpentinization after olivine and pyroxene respectively.

The ophicalcites studied in this contribution consist of an almost continuous, up to $10 \mathrm{~m}$ thick layer of breccia (Fig. $1 \mathrm{~b}$ and c), overlain by massive serpentinites. The contact between serpentinite and breccia is sometimes sharp and lenses of serpentinite interleaved with ophicalcite (Fig. 1c). The total outcrop surface of this unit does not exceed a few hundred square meters. Samples were collected from different zones (c) and (e) in Fig. 1a). The breccia is composed of slightly rounded, veined serpentinite clasts of variable size (up to a few tens of centimeters) embedded in a cement of grey carbonates (Fig. 1e and f). The matrix contains serpentine, locally forming micro-breccia, causing 

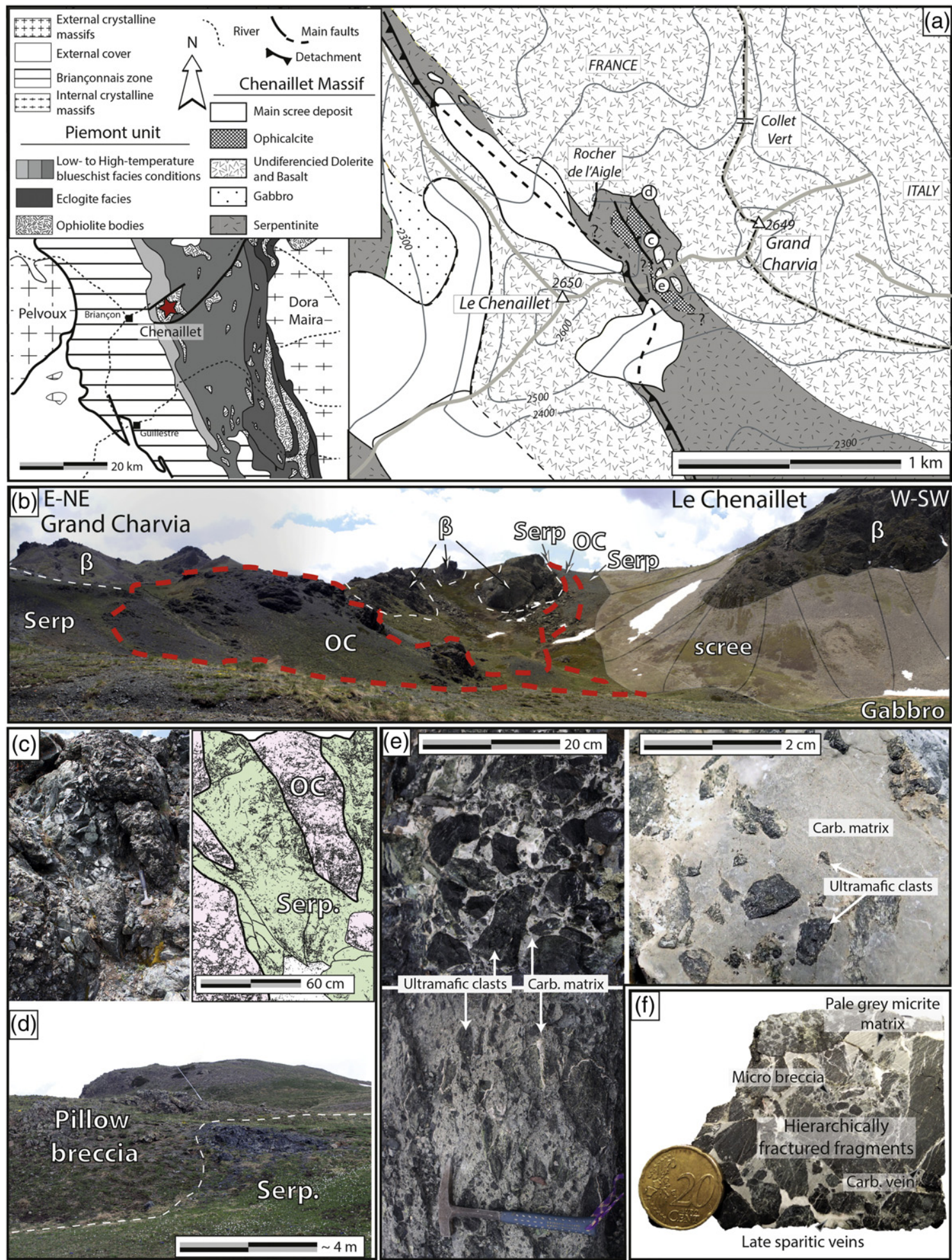

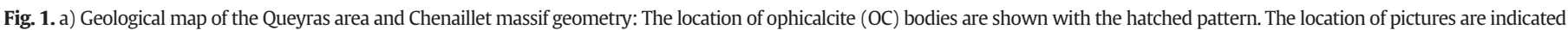

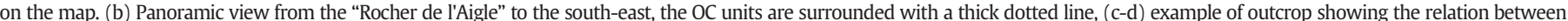

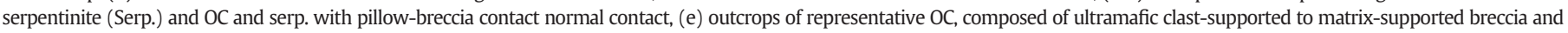
(f) representative sample highlighting the critical textures of the Chenaillet OC; hierarchically fractured serpentinites clasts, matrix of carbonate, sparitic late veins.

darker or lighter shades (Fig. 1e). Finally, it contains pyrite. Previous stable isotopic characterization for Chenaillet ophicalcites report $\delta^{18} \mathrm{O}$ values for breccia cements, the so-called micritic cement. The values have a range between +10.4 and $+12 \%$, (Lemoine et al., 1983). These values were interpreted as calcite formation at high temperature $\left(>100^{\circ} \mathrm{C}\right)$ in the presence of exchanged seawater.
The Chenaillet ophicalcite breccia records the most complete alteration history (including serpentinization and the different carbonation events). Two non carbonated massive serpentinites were sampled below the Chenaillet ophicalcite unit. These samples are considered as reference for textural descriptions. The carbonation-precipitation sequence is discussed below in the 
light of textural and geochemical observations made in the ophicalcite breccia.

\section{Analytical procedures}

\subsection{Petrographic description}

The mineralogy, microtextures, and microstructures were investigated on polished thin sections using polarized light. Cathodoluminescence microscopy (CL) of carbonate veins and matrix were made using a model 8200 MkII cold cathode luminoscope operating at $15 \mathrm{kV}$ and $500 \mu \mathrm{A}$ attached to a microscope with an Olympus ${ }^{\mathrm{TM}}$ digital camera.

X-ray diffraction (XRD) analyses were performed in the ISTerre laboratory, Grenoble using a Bruker D8powder diffraction instrument with a solid state Li-doped silicon detector (SolX Si (Li), Baltic Scientific Instruments) with a $\mathrm{Cu} \mathrm{X}$-ray source. Fragments of rock samples (few cubic millimeter) were cut and crushed manually. The powders were carefully compressed and analyzed over the range $10^{\circ}$ to $80^{\circ}(2 \theta)$, $0.024^{\circ}$ step and $8 \mathrm{~s}$ counting time.

In-situ Raman spectroscopy on serpentine minerals was obtained at the ENS-Lyon using a Horiba Jobin-Yvon LabRam HR800 apparatus in order to determine serpentine varieties. Argon laser with a wavelength of $514 \mathrm{~nm}$ was used. An Olympus ${ }^{\mathrm{TM}}$ BX30 open microscope equipped with a 100 objective was used to focus the laser beam onto an area $1 \mu \mathrm{m}$ diameter. The acquisition of the reflected Raman signal was accumulated for $120 \mathrm{~s}$ in two cycles, with a laser power at the sample surface of approximately $700 \mu \mathrm{W}$. The signal was analyzed using a 1800 lines/mm grating.

\subsection{Grain size analysis}

Samples were analyzed on the thin section surface. Selected rock fragments were hand-polished and acid-etched with dilute (1:10) $\mathrm{HCl}$ acid for $10 \mathrm{~s}$ to determine the shape and sizes of carbonate grains using BSE X-ray spectroscopy on a Mira LMU scanning electron microscope equipped with a Schottky-FEG in ISTE laboratory (Lausanne). From the etched-surface, crystal size distribution (CSD) analyses for carbonate matrix was done. The CSD analyses provides information on the relationship between nucleation and growth. The resolution of the images used for CSD measurements is approximately $1 \mu \mathrm{m} /$ pixel. This leads to a minimum detected grain size of ca. $3 \mu \mathrm{m}$ for the CSD. Calcite crystals consist of blocky prisms. The maximum intersection lengths were measured for individual calcite grains. The values were corrected using the program CSDCorrections (Higgins, 2000) for 2D intersection probabilities.

\subsection{Chemical analysis}

Major element concentrations were determined using a JEOL 8200 Superprobe at UNIL equipped with 5 WD spectrometers and an EDS. Operating conditions of $15 \mathrm{kV}$ with a current of $10 \mathrm{nA}$ or 6-10 nA and on focussed to a $1 \mu \mathrm{m}$ beam for serpentine and defocussed $15 \mu \mathrm{m}$ beam diameter for carbonates to avoid mineral alteration. The limit of detection for individual elements and minerals is given in the captions of Tables 1 and 2. The standards used and the error is provided in Appendix.

Element X-ray maps were acquired with a Jeol JXA-8230 electronmicroprobe at ISTerre (Grenoble) using combined WDS/EDS with mapping with a spot size of $1 \mu \mathrm{m}$ per pixel and $60 \mathrm{~ms}$ of counting time per pixel. For an accelerating voltage of $15 \mathrm{kV}$ the spatial resolution is about $7 \mu \mathrm{m}$.

\subsection{Stable isotope analyses of carbonates and silicates}

Carbonate powders were obtained by micro-drilling from selected areas. Powders were analyzed for $\mathrm{C}$ and $\mathrm{O}$ isotopic ratios using a ThermoFinnigan Gasbench II coupled to a Delta ${ }^{\text {plus } X L}$ dual-inlet isotope ratio mass spectrometer (IRMS) at UNIL following the method of Spötl and Vennemann (2003).

All samples were washed in ethanol. Between $10 \mu \mathrm{g}$ and $200 \mu \mathrm{g}$ of dried material was loaded for isotopic analysis, depending on carbonate content. A Carrara Marble standard was used as internal reference. Results are reported relative to VPDB for carbon and VSMOW for oxygen. The standard deviation $(\sigma)$ for all analyses is better than $0.14 \%$ for carbon and $0.20 \%$ o for oxygen with $80 \%$ of measurements below $0.08 \%$. The reproducibility of measurement is better than 0.06 and $0.16 \%$ in $\delta^{13} \mathrm{C}$ and $\delta^{18} \mathrm{O}$ respectively.

Oxygen isotope ratio of eight serpentine samples were obtained by laser-heating fluorination analysis (e.g. Kaseman et al., 2001). Serpentinite fractions of sub-millimeter fragments were weighed (1.5-2mg), mixed with the same amount of barium fluoride and placed in Pt-sample tray. Samples were dried for one day in an oven at $110^{\circ} \mathrm{C}$ and kept at least two days before analyses to avoid any water contamination linked to the hygroscopic properties of serpentine. Oxygen was extracted from serpentine using a $\mathrm{CO}_{2}$ laser fluorination line and measured using a ThermoFinnigan MAT 253 mass spectrometer. Data were calibrated with the in-house LS-1 quartz standard. The $\delta^{18} \mathrm{O}$ reproducibility is better than $\pm 0.1 \%$ o $(\sigma)$.

Table 1

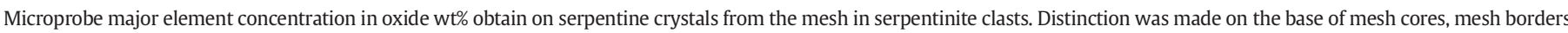

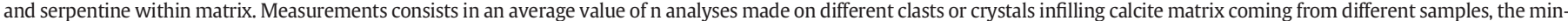

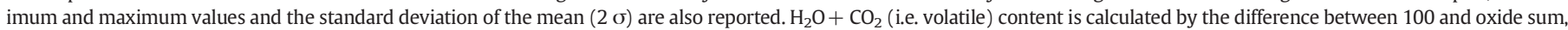
and $\mathrm{X}_{\mathrm{Mg}}$ consist in molar $\mathrm{Mg} /(\mathrm{Mg}+\mathrm{Fe})$. b.d.l.: below detection limit. Detection limit is typically $140 \mathrm{ppm}$ for $\mathrm{Ni}, \mathrm{Cr}$ and $\mathrm{Mn}, 120 \mathrm{ppm}$ for Ti, $100 \mathrm{ppm}$ for $\mathrm{Na}$, and $60 \mathrm{ppm}$ for $\mathrm{K}$.

\begin{tabular}{|c|c|c|c|c|c|c|c|c|c|c|c|c|}
\hline \multirow[t]{2}{*}{ Serpentine habitus } & \multirow{2}{*}{$\frac{\text { Mesh core }}{\text { Average value }}$} & \multicolumn{3}{|c|}{$\mathrm{n}=66$} & \multirow{2}{*}{$\frac{\text { Mesh border }}{\text { Average value }}$} & \multicolumn{3}{|c|}{$\mathrm{n}=67$} & \multirow{2}{*}{$\frac{\text { Within matrix }}{\text { Average value }}$} & \multicolumn{3}{|c|}{$\mathrm{n}=50$} \\
\hline & & Min & Max & 2 sigma & & Min & Max & 2 sigma & & Min & $\operatorname{Max}$ & 2 sigma \\
\hline $\mathrm{SiO}_{2}$ & 41.92 & 39.28 & 44.04 & 0.75 & 41.57 & 39.84 & 43.87 & 0.98 & 41.01 & 38.74 & 43.01 & 5.14 \\
\hline $\mathrm{MgO}$ & 37.77 & 34.47 & 40.00 & 1.07 & 39.21 & 34.03 & 41.28 & 1.63 & 39.94 & 36.41 & 42.26 & 5.44 \\
\hline $\mathrm{FeO}$ & 4.61 & 3.98 & 5.58 & 0.35 & 5.17 & 2.15 & 9.37 & 1.75 & 2.03 & 1.30 & 3.62 & 0.56 \\
\hline $\mathrm{Al}_{2} \mathrm{O}_{3}$ & 2.62 & 0.29 & 3.40 & 0.60 & 0.58 & 0.12 & 2.57 & 0.39 & 0.76 & 0.40 & 2.34 & 0.36 \\
\hline $\mathrm{TiO}_{2}$ & 0.03 & b.d.l. & 0.04 & 0.01 & 0.03 & b.d.l. & 0.04 & 0.01 & 0.06 & 0.02 & 0.40 & 0.10 \\
\hline $\mathrm{NiO}$ & 0.21 & 0.06 & 0.40 & 0.10 & 0.31 & 0.23 & 0.40 & 0.05 & 0.21 & 0.07 & 0.50 & 0.09 \\
\hline $\mathrm{MnO}$ & 0.05 & b.d.l. & 0.09 & 0.02 & 0.06 & b.d.l. & 0.13 & 0.03 & 0.06 & 0.02 & 0.16 & 0.04 \\
\hline $\mathrm{CaO}$ & 0.09 & 0.04 & 0.20 & 0.04 & 0.08 & 0.03 & 0.29 & 0.06 & 0.27 & 0.01 & 0.91 & 0.23 \\
\hline $\mathrm{Na}_{2} \mathrm{O}$ & 0.05 & b.d.l. & 0.11 & 0.02 & 0.04 & b.d.l. & 0.07 & 0.01 & 0.05 & 0.03 & 0.08 & 0.02 \\
\hline $\mathrm{K}_{2} \mathrm{O}$ & 0.03 & b.d.l. & 0.06 & 0.01 & 0.03 & b.d.l. & 0.07 & 0.01 & 0.06 & 0.02 & 0.30 & 0.08 \\
\hline $\mathrm{Cr}_{2} \mathrm{O}_{3}$ & 0.13 & b.d.l. & 0.50 & 0.12 & 0.09 & b.d.l. & 0.42 & 0.10 & 0.08 & 0.05 & 0.17 & 0.04 \\
\hline Total & 87.12 & 81.80 & 91.75 & 1.52 & 86.75 & 83.79 & 89.67 & 1.21 & 84.30 & 80.3 & 88.0 & 10.48 \\
\hline $\mathrm{H}_{2} \mathrm{O}$ & 12.88 & 8.25 & 18.20 & 1.52 & 13.25 & 10.33 & 16.21 & 1.21 & 15.56 & 11.99 & 18.9 & 2.58 \\
\hline $\mathrm{X}_{\mathrm{Mg}}$ & 0.94 & 0.92 & 0.95 & 0.01 & 0.94 & 0.88 & 0.97 & 0.12 & 0.97 & 0.95 & 0.98 & 0.01 \\
\hline
\end{tabular}


Table 2

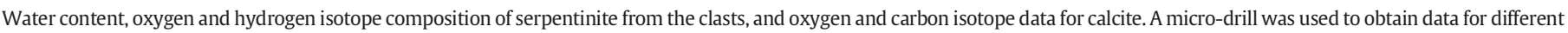
textures. $\mathrm{N}$ correspond to the number of analyses. Temperature were calculated as explained in the text and results are reported in Fig. 10. All data are provided in the Appendix.

\begin{tabular}{|c|c|c|c|c|c|c|c|}
\hline \multirow[t]{2}{*}{ Serpentinite habitus $(\mathrm{N})$} & \multirow{2}{*}{$\begin{array}{l}\delta^{18} \mathrm{O} \\
(\mathrm{VSMOW})\end{array}$} & & \multirow{2}{*}{$\begin{array}{l}\delta \mathrm{D} \\
(\mathrm{VSMOW})\end{array}$} & & \multirow{2}{*}{$\begin{array}{l}\mathrm{H}_{2} \mathrm{O} \text { content } \\
(\mathrm{wt} \%)\end{array}$} & \multirow{2}{*}{$\frac{\mathrm{T}\left({ }^{\circ} \mathrm{C}\right)}{\delta{ }^{18} \mathrm{O}_{\text {fluid }}=0 \% \text { 。 }}$} & \multirow{2}{*}{$\frac{\mathrm{T}\left({ }^{\circ} \mathrm{C}\right)}{\delta^{18} \mathrm{O}_{\text {fluid }}=2 \%}$} \\
\hline & & & & & & & \\
\hline Mesh (ref) & 5.09 & & -148 & & 12.06 & 155 & 190 \\
\hline Bastite (ref) & 3.3 & & -132 & & 11.93 & 190 & 245 \\
\hline Mesh (5) & $3.9 / 5.11$ & & -145 & & 12.98 & $155-175$ & $190-225$ \\
\hline Bastite (4) & $3.28 / 4.23$ & & -138 & & 12.39 & $170-190$ & $215-250$ \\
\hline \multirow[t]{3}{*}{ Calcite texture $(\mathrm{N})$} & \multirow{2}{*}{\multicolumn{2}{|c|}{$\begin{array}{l}\delta^{18} \mathrm{O}(\%) \\
\text { (VSMOW) }\end{array}$}} & & \multirow{2}{*}{\multicolumn{2}{|c|}{$\begin{array}{l}\delta^{13} \mathrm{C}(\% \circ) \\
(\mathrm{VPDB})\end{array}$}} & $\mathrm{T}\left({ }^{\circ} \mathrm{C}\right)$ & $\mathrm{T}\left({ }^{\circ} \mathrm{C}\right)$ \\
\hline & & & & & & $\delta^{18} \mathrm{O}_{\text {fluid }}=0 \%$ & $\delta^{18} \mathrm{O}_{\text {fluid }}=2 \%$ \\
\hline & Range & Mean & & Range & Mean & Range & Range \\
\hline Vein within clast (41) & $10.75 / 16.5$ & 13.2 & & $-1.8 / 0$ & -0.5 & $110-180$ & $130-220$ \\
\hline Mesh core (25) & $12.2 / 14.9$ & 13.3 & & $-5.2 /-0.12$ & -1.1 & $130-160$ & $150-195$ \\
\hline Matrix (26) & $11.5 / 12.6$ & 12.1 & & $-0.8 / 0.3$ & -0.4 & $155-170$ & $185-205$ \\
\hline Late veins (17) & $12.8 / 15.8$ & 14.2 & & $-0.8 / 0.45$ & -0.2 & $120-155$ & $150-180$ \\
\hline
\end{tabular}

\subsection{Analysis of water content in serpentinites and hydrogen isotope ratios}

Water content and $\delta \mathrm{D}$ values of serpentinite were analyzed with a high temperature conversion elemental analyzer (TC/EA) coupled to a gas chromatographic column and the ThermoFinnigan MAT 253 mass spectrometer. Pre-heating of samples and overnight storage in a vacuum desiccator was used to remove adsorbed water.

\section{Results}

\subsection{Petrology of the Chenaillet ophicalcites}

Schematic representation of the complex fabrics of ophicalcites and serpentinites are shown in Fig. 2, along with selected mineral assemblages. Relict textures in serpentine clasts reflect the original peridotite mineralogy of pyroxene, olivine, and spinel and their initial distribution. Serpentine aggregates with characteristic mesh textures (typical mesh size $<1 \mathrm{~mm}$ ) are delineated by $\mu \mathrm{m}$-sized magnetite crystals. They resulted from the interaction of olivine with hydrothermal fluids. The serpentinized pyroxenes are present as large bastites pseudomorphs, often associated with spinel, which is surrounded by chlorite (e.g. Fig. 2c).

Serpentine forms the framework of the rock, while the carbonates form a discrete network of thin, micrometric to millimetric interconnected, cross-cutting veins (Fig. 2). Several generations of carbonate veins and cement can be distinguished at thin section and sample scale (e.g. Figs. $1 \mathrm{f}$ and 2). Serpentinite clasts in ophicalcites have a similar mineralogy, distribution of pseudomorphs, and microtextures as those of non-brecciated fresh serpentinites (Fig. 2b). This suggests that the ultramafic basement constitutes the source for the ultramafic clasts. The bastite versus mesh proportion in clasts is generally $<1 / 5$ and spinel and magnetite represent $<5 \%$ volume.

The modal amount of carbonate and ultramafic clasts vary considerably, as well as veining intensity (Fig. 1). The selected example shown in Fig. 1f displays all salient feature of ophicalcite that will be discussed in detail. Its mineralogy is mainly serpentine and calcite, as shown in the diffraction pattern given for bulk ophicalcite in Fig. 3 .

Raman analysis can discriminate different kinds of serpentine (lizardite, chrysotile, antigorite) (e.g., Groppo et al., 2006; Schwartz et al., 2013). The distribution of different serpentine varieties within ophicalcite is not random but is related to specific rock textures.

Lizardite is the most common serpentine variety in the clasts. It is the most common kind of serpentine formed during oceanic serpentinitization (Andreani et al., 2007). An assemblage of chrysotile + lizardite was observed in the core of mesh textures (e.g. Fig. 4 spectra 2 and 3; see also SEM observation), whereas mesh rims are formed by well-crystallized lizardite (e.g. Figs. $2 d$ and 4 spectrum 1 ). These observations are comparable to observations made on oceanic serpentinites (Boudier et al., 2010; Cressey, 1979; Rouméjon et al., 2015; Rouméjon and Cannat, 2014; Wicks and Zussman, 1975). Chrysotile veins crosscutting clasts may be observed as well as rare occurrence of isolated antigorite in clasts or clast fragments (e.g., Fig. 4, spectrum 7). The occurrence of antigorite in an oceanic context is often attributed to local Si-metasomatism, possibly as a consequence of pyroxene serpentinization at greater depth (O'Hanley, 1991; Rouméjon et al., 2015; Schwartz et al., 2013) rather than an increase in temperature. Nevertheless, antigorite is very rare in our samples, and we will not discuss its origin in detail.

\subsubsection{Carbonates within clasts}

An overview of typical features for different carbonates generation is illustrated in Fig. 5 and discussed below.

4.1.1.1. Carbonate veins. Veins in serpentinite clasts are the first generation of carbonates and are referred to as C1 (Fig. 5a). The center of $\mathrm{C} 1$ veins have a uniform dull-orange luminescing calcite (Fig. 5a). However, the borders of the veins display systematically bright orange luminescence, documenting chemical changes during vein formation. X-ray diffraction on selected serpentinite clasts (i.e. selected serpentinized area including small carbonate veins) indicates that the carbonate is dominantly calcite, but some dolomite can be found (Fig. 3 serpentine clasts). These veins are restricted to individual clast, either terminating inside or truncated at the edge of the clast (Figs. 1a and 5e).

4.1.1.2. Sparitic at clast edge. Clasts are occasionally rimmed by sparitic calcite (called $\mathrm{C}^{\prime}$ ' in Fig. 5). Luminescence features are comparable to the one for C1veins (e.g. Fig. 5b). Locally, wide rims develop into subrhombohedral calcite. The fabric indicates growth towards clasts (Fig. 5c). The texture is interpreted to represent early antitaxial type growth (Fisher and Byrne, 1990; Urai et al., 1991) in a vein. These calcite fringes were linked to a previous crack network, C1. They are remnants of veins channeling fluids. The cracks resulted in host rock brecciation.

4.1.1.3. Carbonate in serpentine mesh. The mesh textured serpentinites are locally replaced by carbonates, designated as C2 (Fig. 5b and c). Carbonate cores consist of single calcite crystals. $\mathrm{C} 1$ veins and $\mathrm{C} 2$ cores are linked as illustrated in Fig. 6, suggesting that they precipitated at the same time. The irregular boundary of the single crystal calcite (Fig. 6) suggests that it replaced residual olivine or enstatite crystals. 

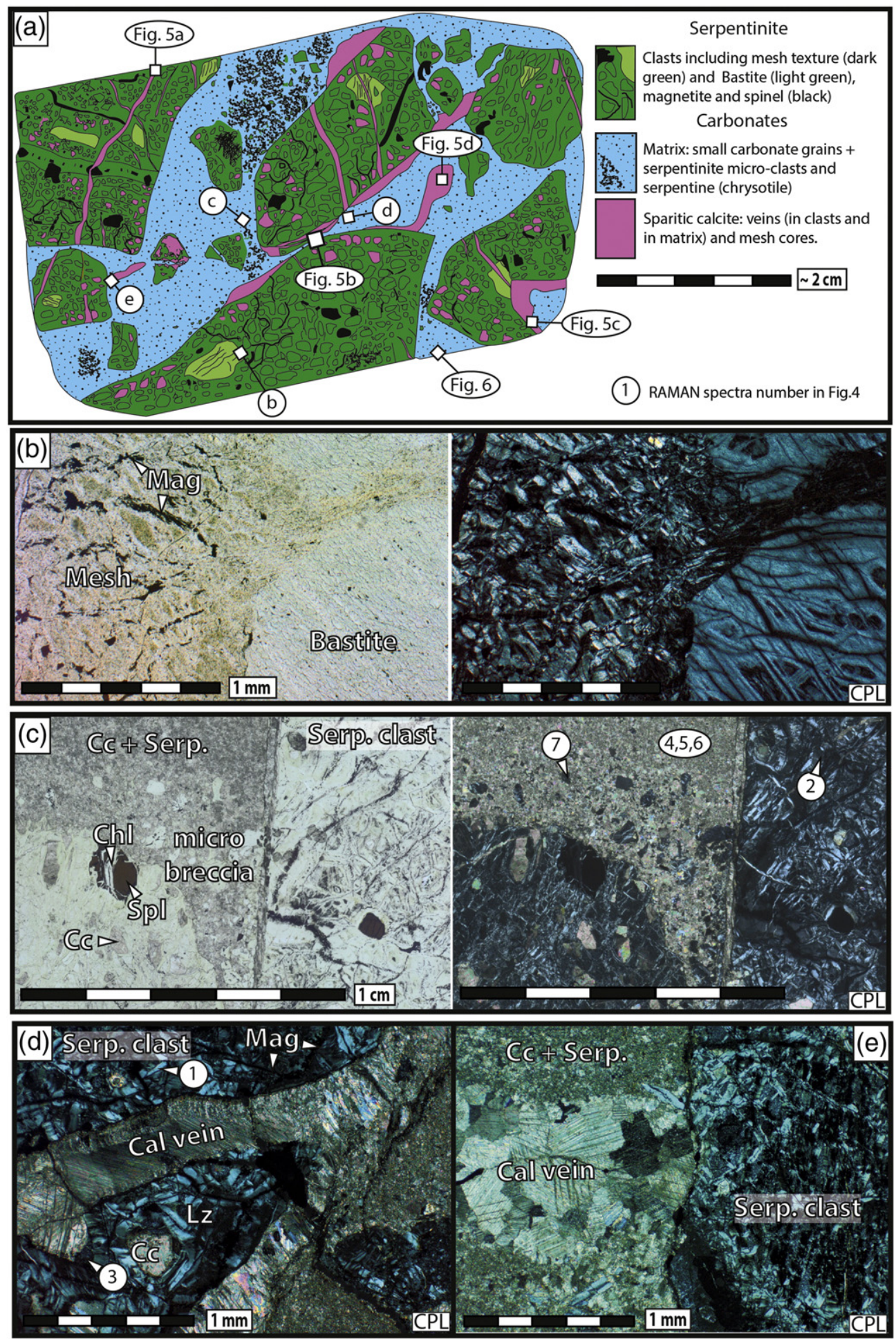

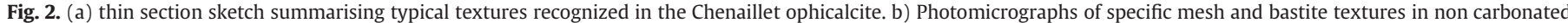

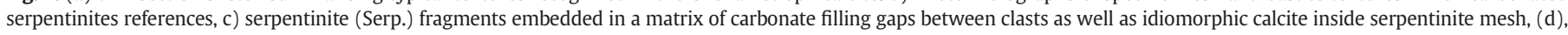

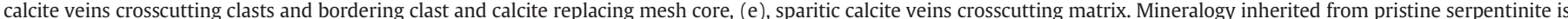

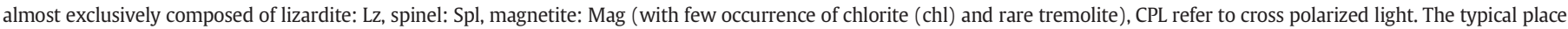
where pictures can be found are reported in (a), the place where RAMAN spectra from Fig. 4 were taken is also reported.

\subsubsection{Micritic matrix supporting clasts}

The Matrix is mainly composed of small calcite grains $(<50 \mu \mathrm{m})$, clast fragments (e.g. Fig. 7d) and tiny serpentine-aggregates (Fig. 7e). Rare magnetite, but no dolomite was detected by X-ray diffraction (Fig. 3 pale grey matrix). Some equant, dozens of micrometer large pyrite crystals were found (e.g. Fig.7b and e). CL images show that the small grains of calcite are zoned, with a dull core and a bright luminescent border (Fig. 7c).

The CSD of the calcite grains forming the cement of the breccia was determined on acid-etched sections (Fig. 7b). For three samples, 1500 grains were measured, from a total area of approximately $0.3 \mathrm{~mm}^{2}$. The relative frequency for mineral sizes from three different samples 


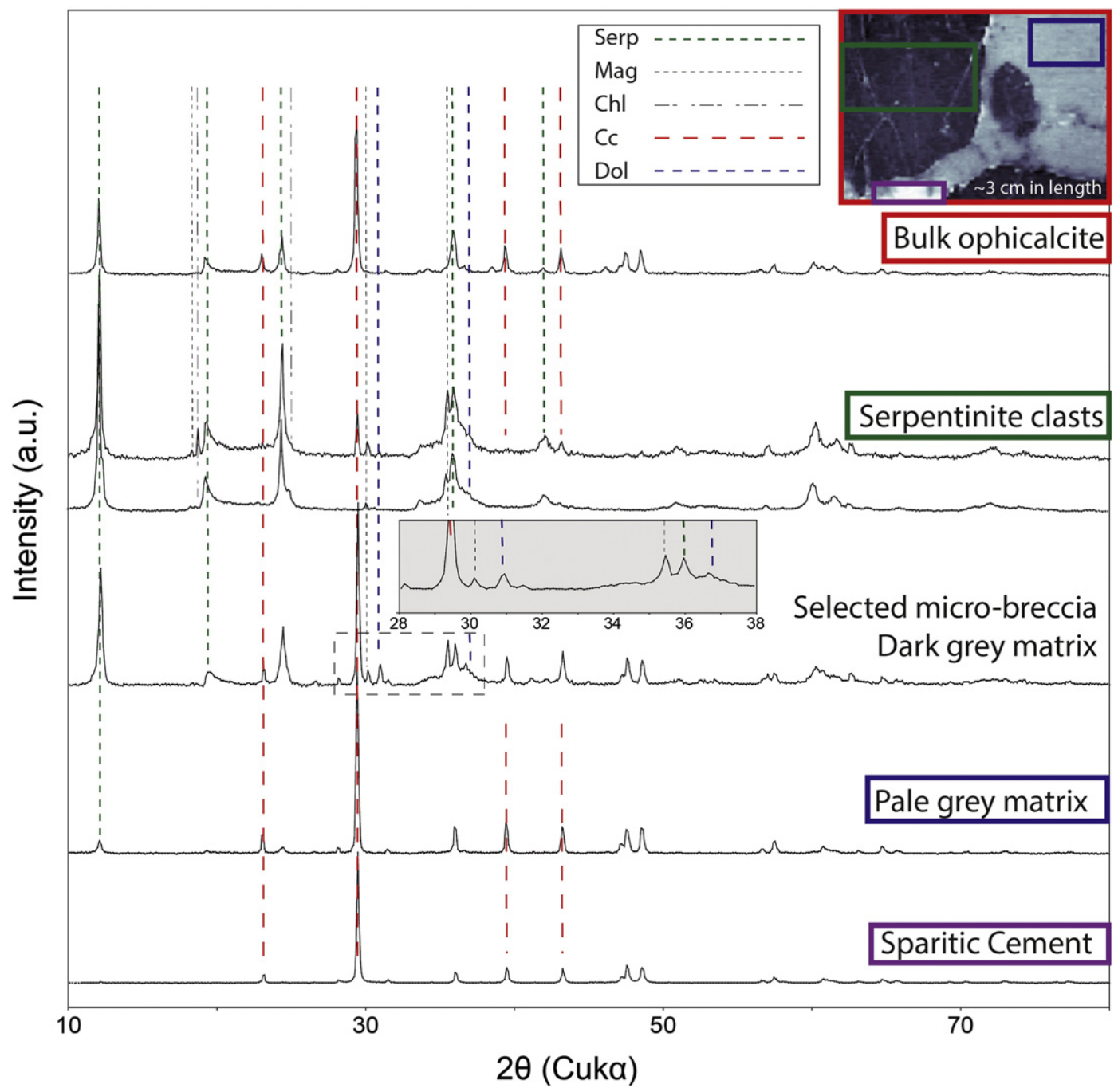

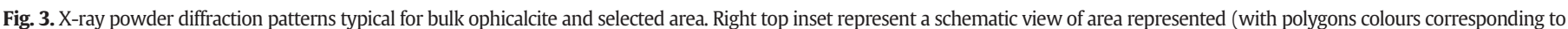

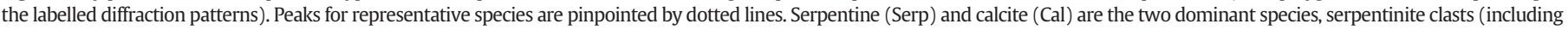

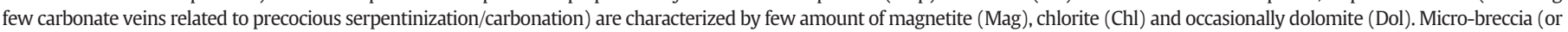

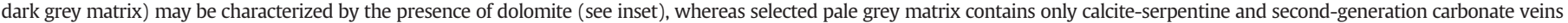
contains only calcite.

is given in Fig. 8. The mineral size distribution has a range from 3 to 60 $\mu \mathrm{m}$. The average particle size is ca. $14 \mu \mathrm{m}$ and the median is ca. $12 \mu \mathrm{m}$. The slope of the CSDs (Fig. 8b) is similar for the 3 samples measured. The slight bend at small grain sizes most likely reflects cumulated uncertainties due to the correction algorithm and the detection limit of $3 \mu \mathrm{m}$. The straight line CSD can be interpreted to reflect a single, continuous nucleation-growth event, with little recrystallization after first formation (Eberl et al., 1998). The calcite crystals are homogeneously distributed in the analyzed sections (Fig. 7). This argues against multiple sources of calcite crystals, from different clastic or bioclastic sources. This is confirmed by stable isotope homogeneity (see below).

The serpentine in the micrometric aggregates (Fig. $7 \mathrm{~d}$ and e) within calcite matrix is exclusively composed of chrysotile (e.g. spectra 6 on Fig. 4). The chrysotile forms acute, delicate clusters (Fig. 7e), suggesting that they were precipitated in situ rather than flushed in as detrital clasts.

Late calcite filled cracks (C4) crosscut the matrix and some of the clasts (Fig. 1f). Veins can reach up to $1 \mathrm{~cm}$ thickness. Intersecting veins and cathodo-luminescence features like geopetals highlights the multiple fluid infiltration and the presence of open vugs (Fig.5d).

\subsubsection{Occurrence of dolomite}

Dolomite is associated with calcite and serpentine in a few carbonated clasts, within fine-grain breccia with carbonate alteration, and in some serpentine layers. Typical textures of the occurrence of dolomite are given in Fig. 9. Dolomite is present as idiomorphic crystals separating calcite and serpentinite at some clast edges (Fig. 9a, c, d) or next to calcite in serpentinite mesh cores and serpentine mesh borders after olivine or orthopyroxene (Fig. 9b). This resembles metamorphic reactions of incompatible minerals, driven either by metasomatism or pressure and temperature changes. A few anastomosing veinlets of dolomite, in places ultramafic fragment crosscut C3 matrix calcite (Fig. 9a). In either case, dolomite is secondary, well after calcite formation.

\subsection{Geochemistry and stable isotope composition of ophicalcite}

\subsubsection{Serpentine}

Microprobe measurements were grouped texturally into serpentine mesh cores, mesh borders and serpentine within matrix. We do not report data for serpentine within bastite. The number of analyses and the analytical error are detailed in Table 1 . Mesh cores display highly homogeneous $\mathrm{MgO}$ and $\mathrm{FeO}$ content with $\mathrm{FeO}$ values between 4 and 5.5 wt\% (Fig. 10a and Table 1). Mesh borders are characterized by a wider range in $\mathrm{FeO}$ content, with values between 2.15 and $9.4 \mathrm{wt} \%$. However, average $\mathrm{X}_{\mathrm{Mg}}(\mathrm{Mg} / \mathrm{Mg}+\mathrm{Fe})$ in cores and borders are comparable (Table 1). Typical value for $\mathrm{X}_{\mathrm{Mg}}$ in the cores is 0.94 whereas $\mathrm{X}_{\mathrm{Mg}}$ for mesh rims is 0.93 (Fig. 10 and Table 1). In addition, the average $\mathrm{Al}_{2} \mathrm{O}_{3}$ 

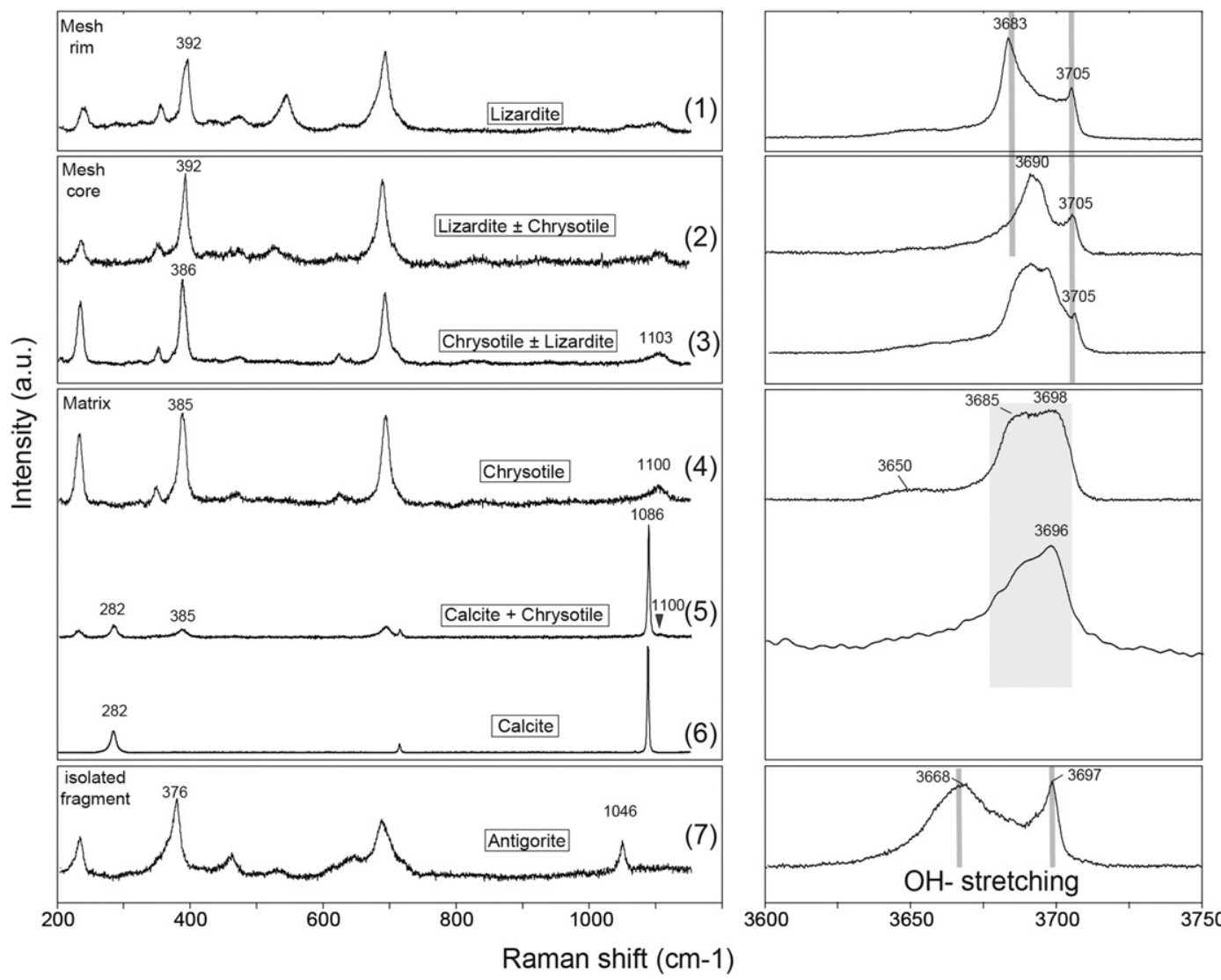

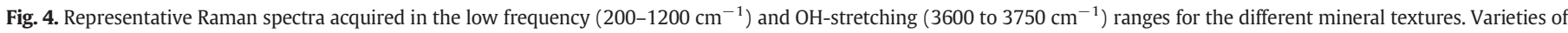

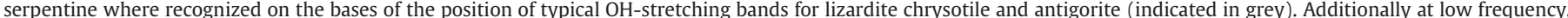

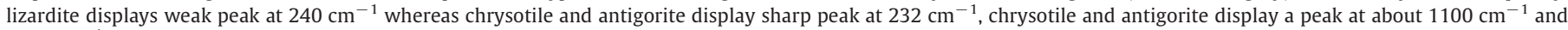
$1043 \mathrm{~cm}^{-1}$ respectively and all peaks are shifted towards lower frequency for antigorite.

content for mesh cores is substantially higher than that for mesh borders with $2.2 \mathrm{wt} \%$ versus $0.6 \mathrm{wt} \%$ (Table 1 and Fig. 10). The higher $\mathrm{Al}_{2} \mathrm{O}_{3}$ content in mesh core might reflect greater Al Tschermak substitution with $\mathrm{Si}$ (Evans, 2008). Note that all Fe was considered as $\mathrm{Fe}^{2+}$. The concentration of $\mathrm{NiO}$ in serpentine is between $0.06 \mathrm{wt} \%$ and $0.4 \mathrm{wt} \%$. Here mesh borders are slightly enriched and much more homogeneous in Ni. Both mesh cores and mesh borders contained $<0.1$ wt\% of all other minor elements.

Powder obtained from micro-drilling serpentinite have homogeneous oxygen isotopic values with a range from +3.3 to $+4.2 \%$ in bastite type serpentinites and +3.9 to $+5.1 \%$ o for mesh type serpentinites (Table 2 and Appendix). Serpentinite has low $\delta \mathrm{D}$ values with a range from -133 to $-148 \%$ o (VSMOW). Based on this limited data set mesh serpentinites are characterized by values 0.5 to $1 \%$ o higher and $\sim 10 \%$ o lower for $\delta^{18} \mathrm{O}$, and $\delta \mathrm{D}$, respectively compared to serpentinite from bastite. Absolute values for water content in serpentinite range between 11.9 and $13 \mathrm{wt} \%$. No correlation between water content and $\delta \mathrm{D}$ values is apparent.

\subsubsection{Carbonates within clasts}

Microprobe-analyzed chemical compositions and isotopic compositions vary between the texturally distinct generations of calcite (Table 3). The number of analyses and the analytical errors are detailed in Table 3. Veins within the clasts contains up to $1.4 \mathrm{wt} \% \mathrm{MgO}$, (0.20 wt\% in average), up to $0.7 \mathrm{wt} \%$ for $\mathrm{FeO}$ (0.09 wt\% in average), and below $0.1 \mathrm{wt} \%$ for all other minor elements (Table 3). The mean $\mathrm{SrO}$ values obtained for the analyzed veins is about $0.04 \mathrm{wt} \%$. Calcite fringes reported as C1' contain values that are comparable to C1 veins with up to $2.1 \mathrm{wt} \%$ of $\mathrm{MgO}$ and slightly higher values for $\mathrm{MnO}$, with a larger range (Table 3 ). In contrast, sparitic calcite characterizing mesh cores contains two to three times higher amount of Mg, and Mn (Table 3) with mean values of $0.46 \mathrm{wt} \%$ and $0.24 \mathrm{wt} \%$ for $\mathrm{MgO}$ and $\mathrm{MnO}$ respectively. Other minor elements displayed values comparable to those measured for $\mathrm{C} 1$ veins with an average value of about $0.05 \mathrm{wt} \%$, $0.08 \mathrm{wt} \%$ and $0.1 \mathrm{wt} \%$ for $\mathrm{SrO}, \mathrm{PbO}$ and $\mathrm{FeO}$ respectively.

Calcites from (C1) veins are marked by relatively homogeneous $\delta^{13} \mathrm{C}$ values (Fig. 11, Table 2 and Appendix). Our values fall in the range of composition reported for other ophicalcites locality from the Alpine belt. All values for $\delta^{13} \mathrm{C}$ are between -1.0 and $0.0 \%$, suggesting a seawater origin for carbon. The $\delta^{18} \mathrm{O}$ values for $\mathrm{C} 1$ carbonate varies between +11 and $+16 \%$. A slightly smaller range of +12 to $+15 \%$ 。 was measured for calcite from (C2) mesh serpentinites. Nevertheless, some mesh cores have low $\delta^{13} \mathrm{C}$ values of $-5 \%$ (Fig. 11). C1' calcite fringes tend towards the heaviest isotopic compositions of the $\mathrm{C} 1$ group (i.e. $\delta^{18} \mathrm{O}>+14 \%$ ).

\subsubsection{Matrix}

Chemical analysis for the calcite matrix have values of 0.02 to $2.9 \mathrm{wt} \%$ for $\mathrm{MgO}$ ( $0.42 \mathrm{wt} \%$ in average). $\mathrm{MnO}$ remains high with $0.13 \mathrm{wt} \%$ in average and the $\mathrm{SrO}$ content is the highest observed for all the different kind of carbonates with concentration up to $0.32 \mathrm{wt} \%$ ( $0.1 \mathrm{wt} \%$ in average).

The isotopic values for calcite in the matrix vary little, both in $\mathrm{C}$ and $\mathrm{O}$ isotope ratios. The values range between +11.6 and $+12.6 \%$ for $\delta^{18} \mathrm{O}$ and the values range between -0.8 and $+0.3 \%$ for $\delta^{13} \mathrm{C}$ (Fig. 11 and Table 2).

Late open calcite cracks are characterized by an average $\mathrm{MgO}$ value of $0.23 \mathrm{wt} \%$. Average values for other minor elements are $0.08 \mathrm{wt} \%$, $0.05 \mathrm{wt} \%, 0.07 \mathrm{wt} \%$ and $0.11 \mathrm{wt} \%$ for $\mathrm{FeO}, \mathrm{SrO}, \mathrm{PbO}$ and $\mathrm{MnO}$, respectively (Table 3 ). The $\delta^{18} \mathrm{O}$ values range between +12.8 and $+15.5 \%$ o with no overlap with values recorded for C3 matrix (Fig. 11). The average value is about $+14 \%$ o (Fig. 11 and Table 2 ). 

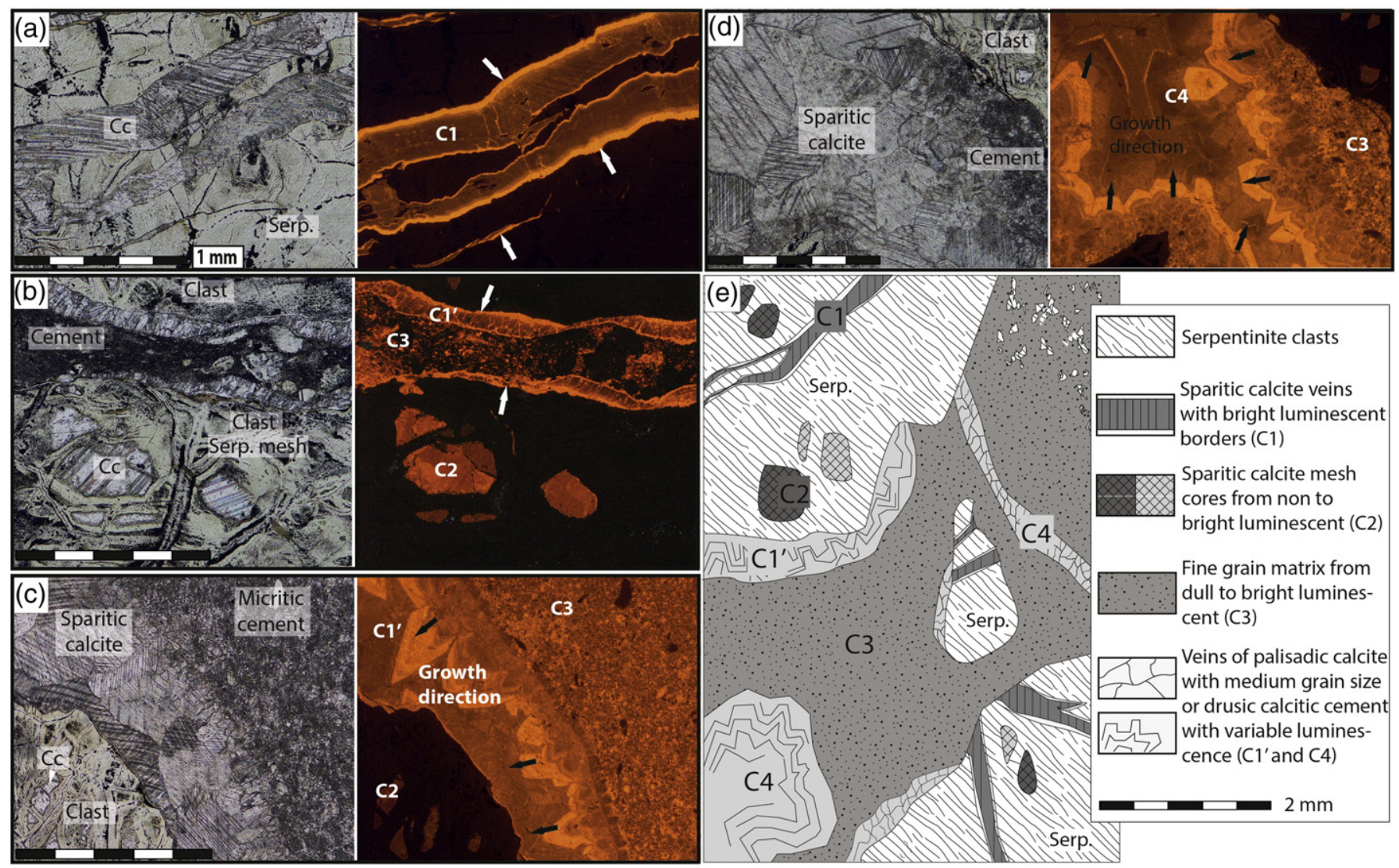

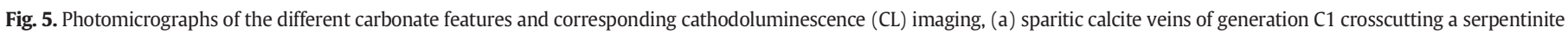

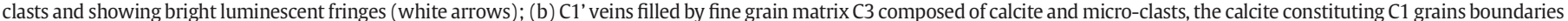

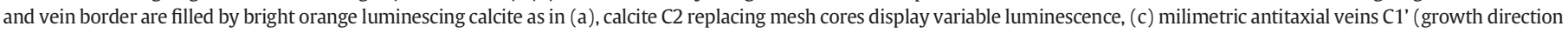

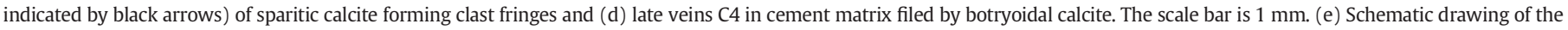
different carbonation features in the Chenaillet ophicarbonates.

EPMA measurements for serpentine within the matrix carbonate have low $\mathrm{Al}_{2} \mathrm{O}_{3}$ content ( $0.76 \mathrm{wt} \%$ in average), a value comparable to the one recorded for serpentinite at the edges of mesh structures (Table 1 and Fig. 10a), but values cover the same range as those of mesh rim serpentine (Fig. 9a). The FeO contents is generally very low, with an average value of $2.03 \mathrm{wt} \%$ leading to $\mathrm{X}_{\mathrm{Mg}}$ of 0.97 . This is higher than values measured for other serpentine $\left(0.93-\mathrm{X}_{\mathrm{Mg}}-0.94\right)$. Values for other minor elements (with the exception of $\mathrm{Ca}$ ) are comparable with values reported above for the other serpentines.

\subsubsection{Dolomite}

Dolomite crystals are characterized by a low content of SrO (0.02 wt,\% on average) but relatively high $\mathrm{MnO}$ (0.19 wt\%, on average) and $\mathrm{FeO}$ contents ( $0.29 \mathrm{wt} \%$ in average, Table 3 ). In the few cases where it was possible to distinguish between different dolomite types we noted that dolomite replacing serpentine close to mesh cores borders are characterized by higher $\mathrm{MnO}$ and $\mathrm{FeO}$ contents than dolomite within the matrix.

\section{Discussion}

\subsection{Thermal constraints for the Chenaillet ophicalcite formation}

\subsubsection{Temperature of serpentinization}

Temperatures for serpentine formation were calculated using the Zheng (1993) fractionation factors for oxygen isotopes between water
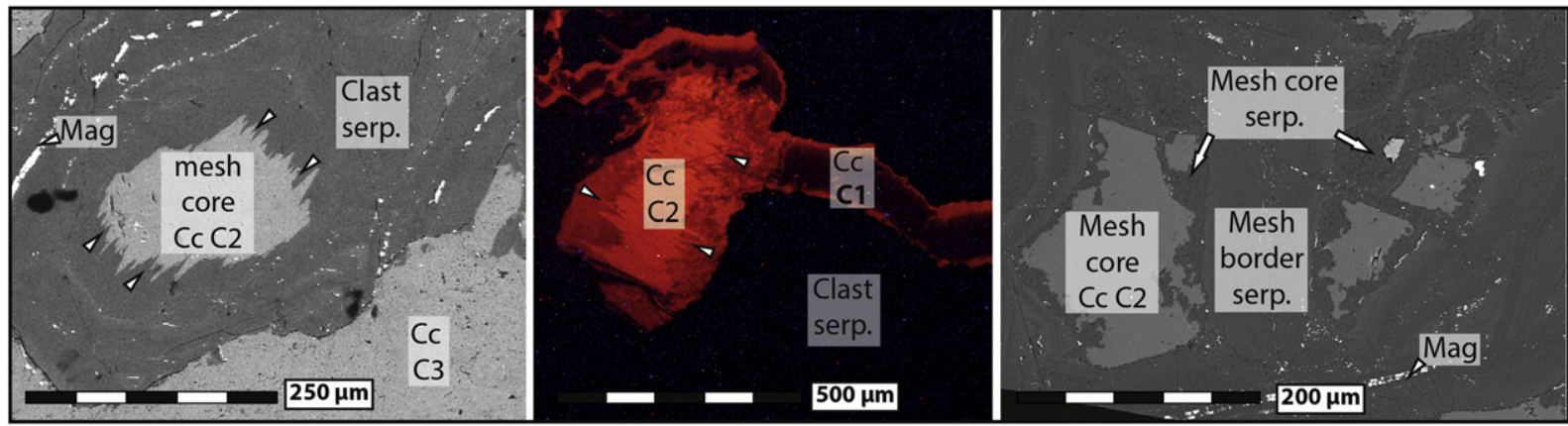

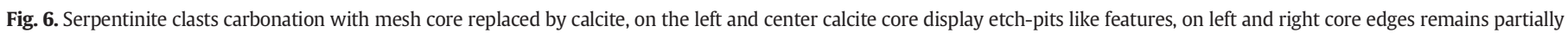
composed of serpentine interpenetrated with calcite while in the center is fully carbonated. 

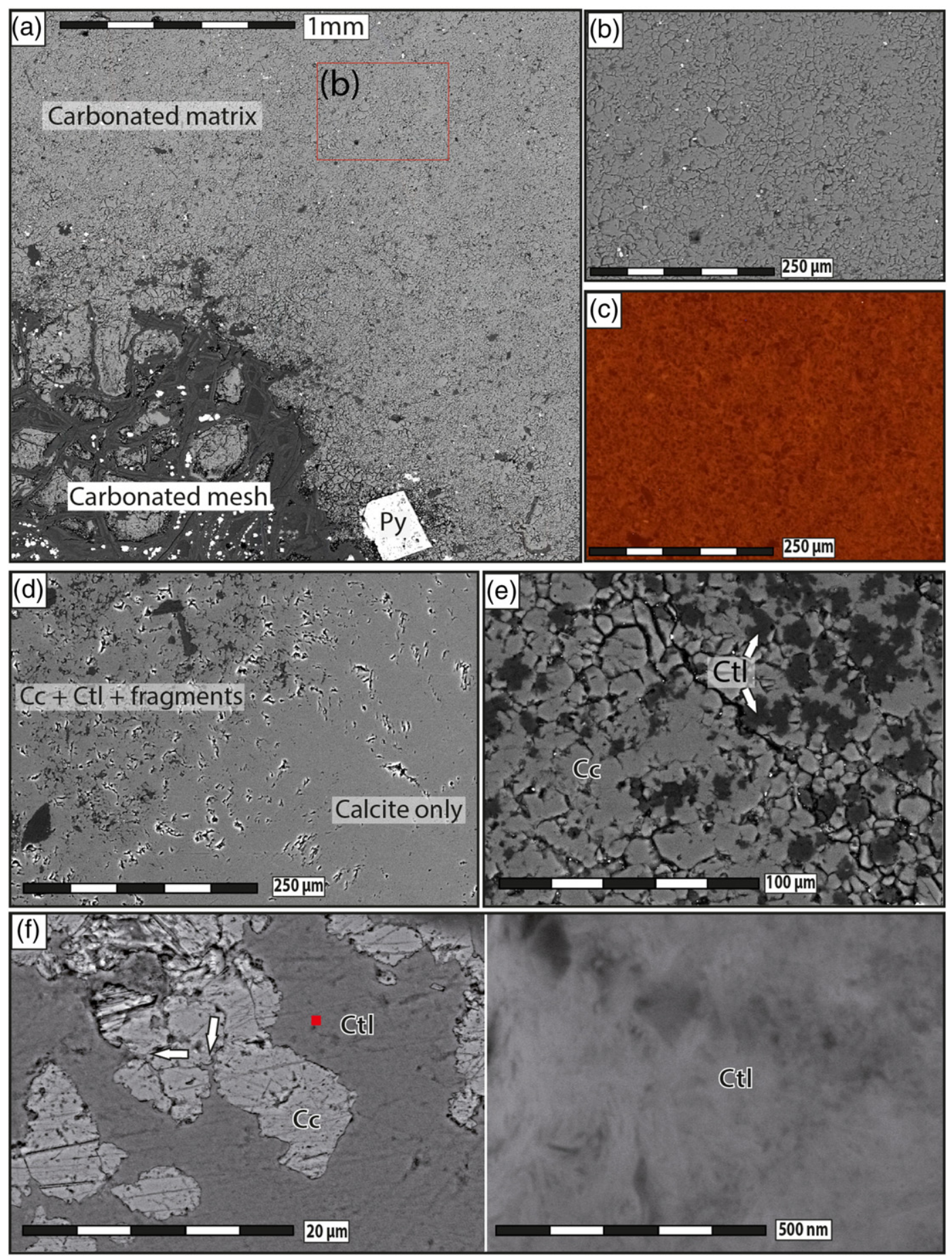

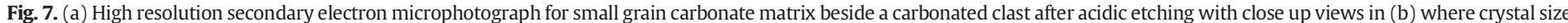

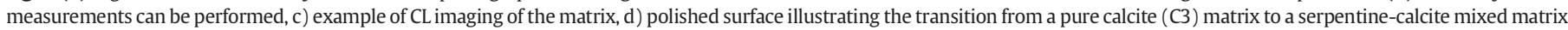
and e-f) example of intergrowth textural features in serpentine-calcite matrix with close up view represented by red polygon, interstitial chrysotile are pinpointed by white arrow.

and serpentine:

$10^{3} \ln \alpha_{\text {serpentine-water }}^{18}=3.99 \times \frac{10^{6}}{T^{2}}-8.12 \times \frac{10^{3}}{T}+2.35$

The serpentinization occurred at temperatures of 155 to $190{ }^{\circ} \mathrm{C}$, assuming a $\delta^{18} \mathrm{O}$ of $0 \%$ for the fluid responsible for alteration (Table 2 and Fig. 12). If the fractionation factor of Saccocia et al. (2009) is used, higher temperatures of 215 and $245{ }^{\circ} \mathrm{C}$ are calculated.

Serpentinites are depleted in deuterium $(-133<\delta \mathrm{D}<-148 \%$ 。), which is common in serpentinites from Alpine ophiolites (Fruh-Green et al., 2001; Früh-Green et al., 1990; Sheppard, 1980). Since the Alpine overprint induced very little textural changes, it is likely that low- $\delta \mathrm{D}$ fluids produced during oceanic peridotite alteration. This might reflects serpentinitization and long residence time in slow spreading system during hydration in the prehnite-pumpellyite facies (e.g. Agrinier et al., 1988).

\subsubsection{Temperature of carbonation}

The temperature of carbonate precipitation is difficult to evaluate, since the veins contain normally only calcite. Nevertheless, assuming an 

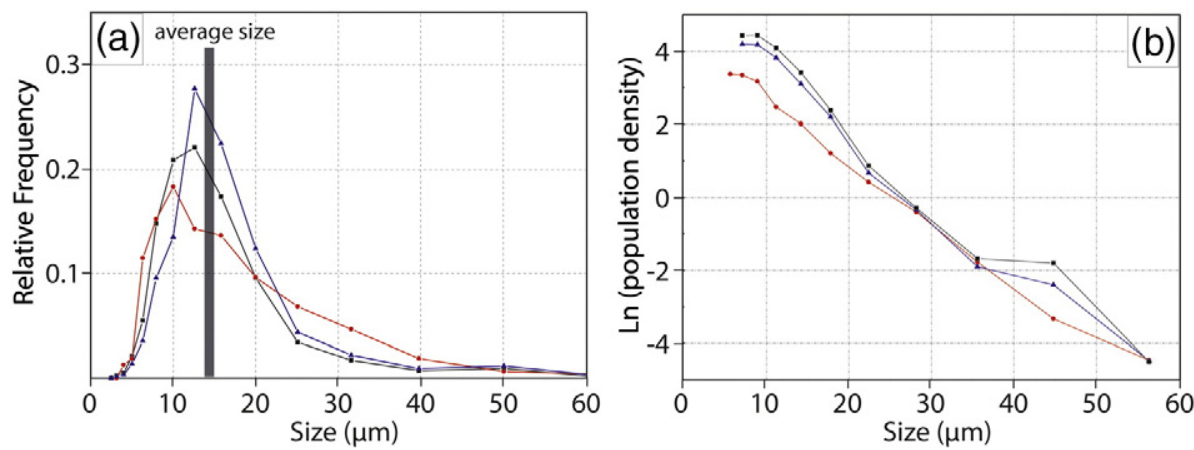

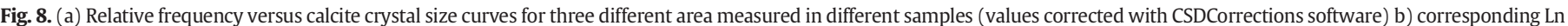
(population density) for the different size intervals.

ocean water isotopic composition of about $0 \%$, temperatures can again be estimated based on carbonate-water fractionation factors. However, the ocean water might have changed its isotopic composition by water-rock interaction prior to precipitation of the carbonate. Hence the obtained temperatures are at best an indication of precipitation temperature.

Using the Kim and O'Neil (1997) fractionation law: $10^{3} \ln$ $\alpha_{\text {calcite-water }}^{18}=4.01 \times \frac{10^{6}}{T^{2}}-4.66 \times \frac{10^{3}}{T}+1.71$ we estimated the possible temperature for carbonates formation (Table 3 and Fig. 12) equilibration with primary seawater composition.
An additional uncertainty is introduced by possible resetting of the isotopic composition during the Alpine overprint. Temperatures estimated for the Alpine metamorphism of the Chenaillet unit are below $250^{\circ} \mathrm{C}$ (Goffé et al., 2004). An upper bound for the diffusion can be estimated by assuming a duration of $5 \mathrm{Ma}$ at peak temperature of $250{ }^{\circ} \mathrm{C}$. A characteristic diffusion distance for oxygen of $<3 \mu \mathrm{m}$ is obtained using the fasted reported diffusion coefficients for oxygen isotopes in calcite (Farver, 1994), while a distance of $<10 \mathrm{~nm}$ is obtained using the most recent diffusion coefficients of Labotka et al. (2000). Hence, we estimate that diffusive exchange is too slow to change the isotopic composition of
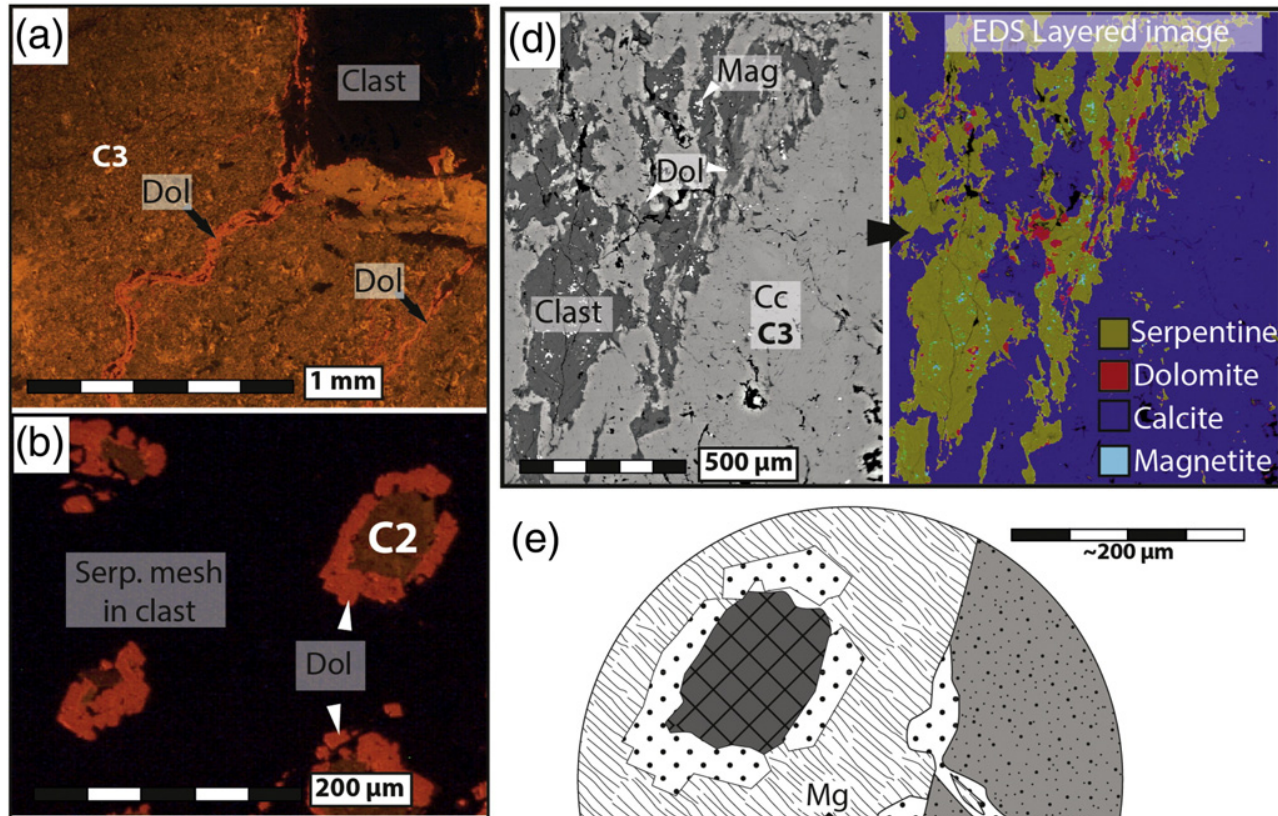

(e)
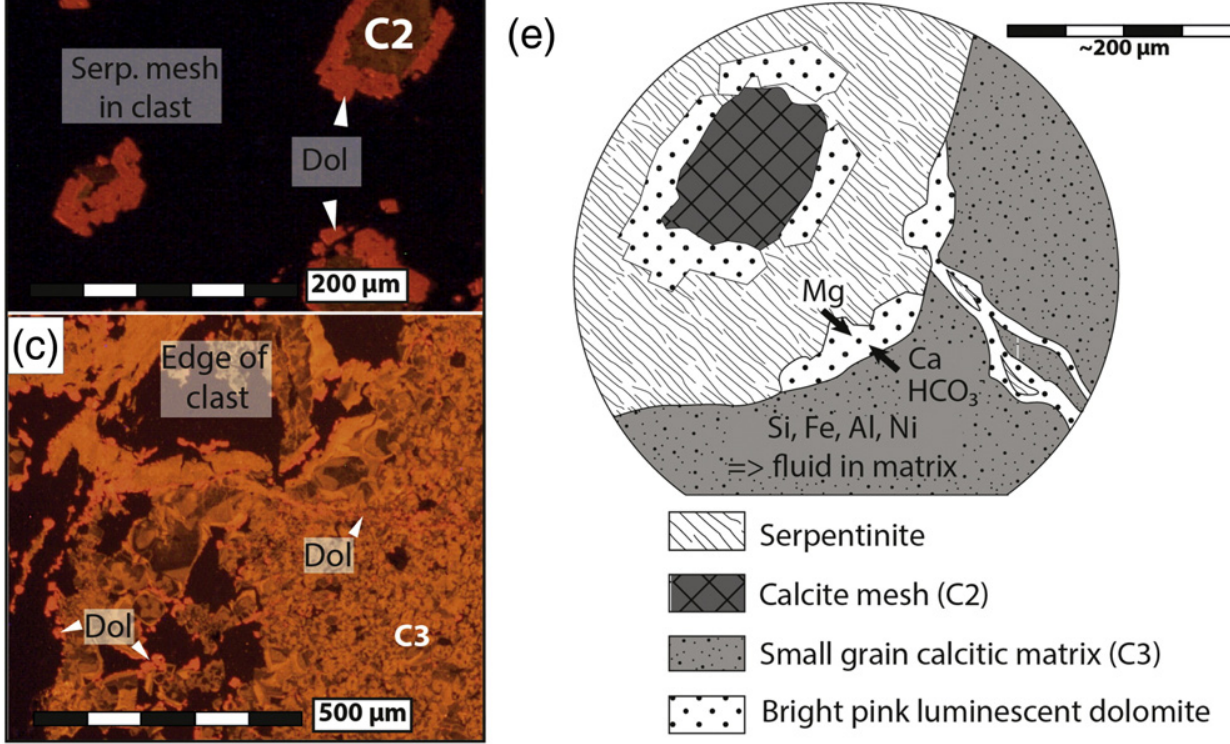

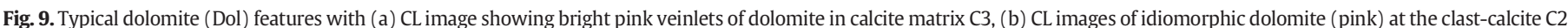

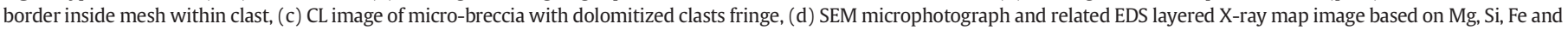

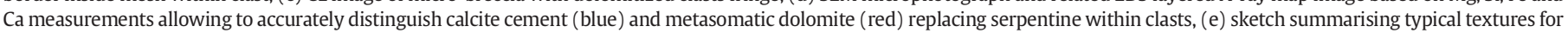
dolomite occurrence. 

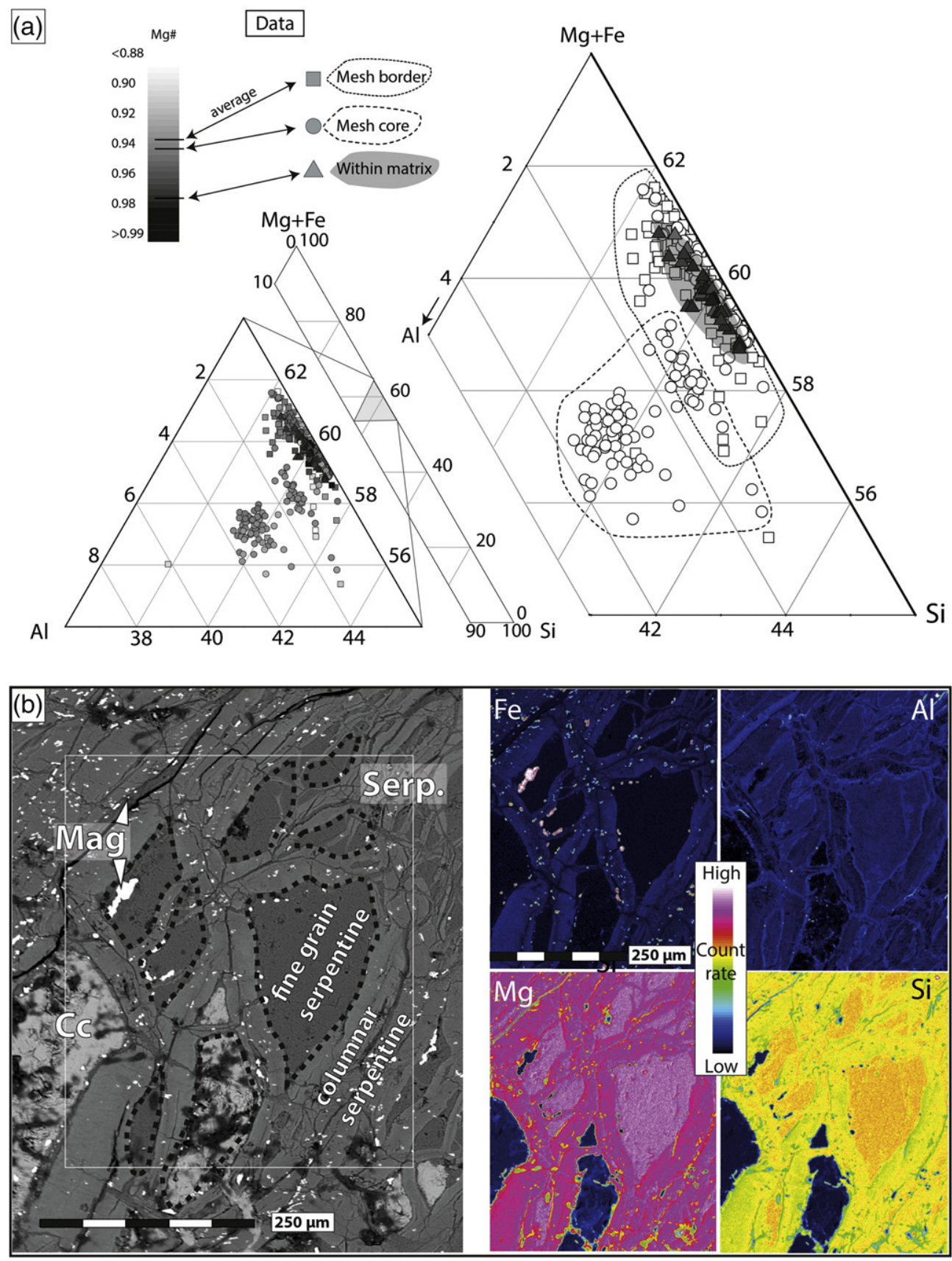

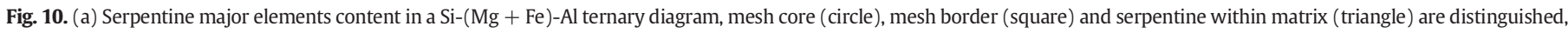

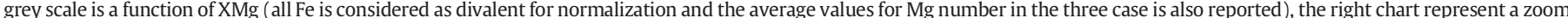

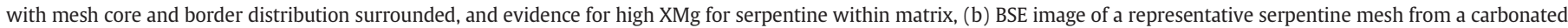

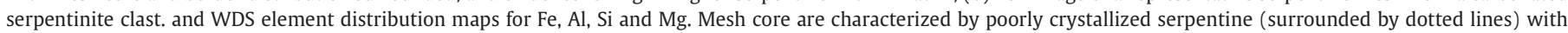

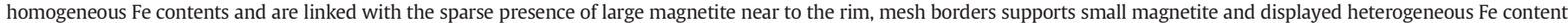
and lowest amount of $\mathrm{Al}$. Cc, calcite; Mag, magnetite; Serp, undifferencied serpentine.

the carbonates. Recrystallization of the carbonates on the other hand can reset the isotopic composition easily (Putnis and Putnis, 2007). Hence, care was taken to use only carbonates that show no textural evidence for recrystallization. The linear crystal size distribution for the matrix carbonates, for example, argues against recrystallization (e.g. Cashman and Ferry, 1988).

Temperature for the formation of the carbonate veins are between $110{ }^{\circ} \mathrm{C}$ and $180{ }^{\circ} \mathrm{C}$ assuming seawater $\delta^{18} \mathrm{O}=0 \%$. The largest calcite veins in the clasts (i.e. $>1 \mathrm{~mm}$ ) generally have lower O-isotopic values when compared to the smaller veins in the clasts $(<1 \mathrm{~mm}$; see e.g. Fig. 12a). This suggests that the latter veins formed at lower temperatures, and the range given reflects this thermal evolution. Mesh core replacement operated at temperatures between 130 and $160{ }^{\circ} \mathrm{C}$. The precipitation of carbonate cement occurred at a temperature of ca. $155-170{ }^{\circ} \mathrm{C}$. Late veins are characterized by lower temperature of formation of $120-155^{\circ} \mathrm{C}$.

Taking the above temperatures at face value, this suggests that the serpentinite clasts went through an initial cooling during clast formation, followed by a moderate reheating before or during cementation, before again cooling is recorded during late stage veining. Alternatively, the data could be interpreted to reflect changes in isotopic composition of the carbonate precipitating fluids. 
Table 3

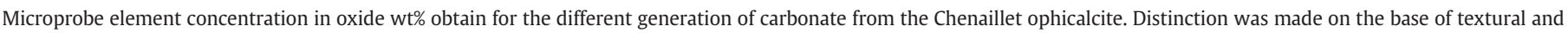

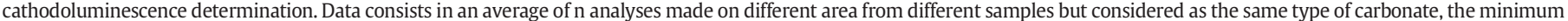

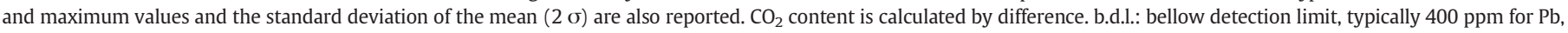
200 ppm for Mn, Sr and Ti and 160 ppm for Fe and Cr in calcite and 200 ppm for Pb, 180 ppm for Mn and close to 130 ppm for Sr, Fe, Ni, Cr and Ti in dolomite.

\begin{tabular}{|c|c|c|c|c|c|c|c|c|c|c|c|c|}
\hline \multirow{4}{*}{$\frac{\text { Carbonate type }}{\mathrm{n}=\text { type }}$} & \multicolumn{4}{|l|}{$\mathrm{C} 1$} & \multicolumn{4}{|l|}{$C 1^{\prime}$} & \multicolumn{4}{|l|}{$\mathrm{C} 2$} \\
\hline & \multirow{2}{*}{\multicolumn{4}{|c|}{$\begin{array}{l}68 \\
\text { Calcite }\end{array}$}} & \multirow{2}{*}{\multicolumn{4}{|c|}{$\begin{array}{l}108 \\
\text { Calcite }\end{array}$}} & \multirow{2}{*}{\multicolumn{4}{|c|}{$\begin{array}{l}81 \\
\text { Calcite }\end{array}$}} \\
\hline & & & & & & & & & & & & \\
\hline & Average & Max & Min & $2 \sigma$ & Average & Max & Min & $2 \sigma$ & Average & Max & Min & $2 \sigma$ \\
\hline \multicolumn{13}{|l|}{ wt\% } \\
\hline $\mathrm{MgO}$ & $<0.20$ & 1.37 & b.d.l. & 0.24 & $<0.19$ & 2.12 & b.d.l. & 0.28 & $<0.46$ & 3.05 & b.d.l. & 0.56 \\
\hline $\mathrm{CaO}$ & 54.00 & 55.64 & 50.01 & 1.43 & 54.04 & 55.54 & 46.11 & 1.61 & 53.20 & 55.91 & 47.88 & 1.76 \\
\hline $\mathrm{FeO}$ & $<0.09$ & 0.71 & b.d.l. & 0.10 & $<0.08$ & 0.34 & b.d.l. & 0.08 & $<0.10$ & 0.60 & b.d.l. & 0.10 \\
\hline $\mathrm{SrO}$ & $<0.04$ & 0.07 & b.d.l. & 0.02 & $<0.05$ & 0.08 & b.d.l. & 0.03 & $<0.05$ & 0.09 & b.d.l. & 0.03 \\
\hline $\mathrm{MnO}$ & $<0.09$ & 0.17 & b.d.l. & 0.05 & $<0.11$ & 0.35 & b.d.l. & 0.09 & $<0.24$ & 0.63 & b.d.l. & 0.19 \\
\hline $\mathrm{NiO}$ & $<0.05$ & 0.09 & b.d.l. & 0.02 & $<0.04$ & 0.06 & b.d.l. & 0.02 & $<0.05$ & 0.10 & b.d.l. & 0.02 \\
\hline $\mathrm{PbO}$ & $<0.08$ & 0.15 & b.d.l. & 0.04 & $<0.07$ & 0.13 & b.d.l. & 0.04 & $<0.08$ & 0.14 & b.d.l. & 0.04 \\
\hline $\mathrm{Cr}_{2} \mathrm{O}_{3}$ & $<0.04$ & 0.10 & b.d.l. & 0.02 & $<0.03$ & 0.05 & b.d.l. & 0.01 & $<0.04$ & 0.06 & b.d.l. & 0.01 \\
\hline $\mathrm{TiO}_{2}$ & $<0.03$ & 0.04 & b.d.l. & 0.01 & $<0.03$ & 0.04 & b.d.l. & 0.01 & $<0.05$ & 0.07 & b.d.l. & 0.01 \\
\hline $\mathrm{CO}_{2}$ & 42.60 & 43.79 & 39.74 & 0.99 & 42.68 & 43.59 & 36.31 & 1.14 & 42.32 & 43.90 & 39.47 & 1.11 \\
\hline Total & 97.41 & 99.67 & 93.32 & 1.52 & 97.33 & 100.06 & 93.67 & 1.99 & 97.1 & 99.84 & 94.07 & 1.82 \\
\hline \multirow{4}{*}{$\begin{array}{l}\text { Carbonate type } \\
\mathrm{n}=\text { type }\end{array}$} & \multicolumn{4}{|l|}{ C3 } & \multicolumn{4}{|l|}{ C4 } & \multicolumn{4}{|l|}{ Dol } \\
\hline & \multirow{2}{*}{\multicolumn{4}{|c|}{$\begin{array}{l}89 \\
\text { Calcite }\end{array}$}} & \multirow{2}{*}{\multicolumn{4}{|c|}{$\begin{array}{l}69 \\
\text { Calcite }\end{array}$}} & \multirow{2}{*}{\multicolumn{4}{|c|}{$\begin{array}{l}50 \\
\text { Dolomite }\end{array}$}} \\
\hline & & & & & & & & & & & & \\
\hline & Average & Max & Min & $2 \sigma$ & Average & Max & Min & $2 \sigma$ & Average & Max & Min & $2 \sigma$ \\
\hline \multicolumn{13}{|l|}{ wt\% } \\
\hline $\mathrm{MgO}$ & $<0.45$ & 2.89 & b.d.l. & 0.49 & $<0.23$ & 2.05 & b.d.l. & 0.26 & 19.35 & 21.12 & 16.40 & 1.26 \\
\hline $\mathrm{CaO}$ & 54.42 & 56.17 & 51.69 & 0.87 & 53.87 & 56.09 & 48.91 & 1.51 & 31.66 & 35.77 & 30.10 & 1.57 \\
\hline $\mathrm{FeO}$ & $<0.09$ & 0.31 & b.d.l. & 0.06 & $<0.08$ & 0.58 & b.d.l. & 0.07 & $<0.29$ & 0.82 & 0.08 & 0.22 \\
\hline $\mathrm{SrO}$ & 0.10 & 0.32 & 0.03 & 0.09 & $<0.05$ & 0.09 & b.d.l. & 0.02 & $<0.03$ & 0.05 & b.d.l. & 0.01 \\
\hline $\mathrm{MnO}$ & $<0.13$ & 0.46 & b.d.l. & 0.10 & $<0.11$ & 0.40 & b.d.l. & 0.08 & 0.19 & 0.24 & 0.15 & 0.02 \\
\hline $\mathrm{NiO}$ & $<0.04$ & 0.06 & b.d.l. & 0.01 & $<0.04$ & 0.05 & b.d.l. & 0.01 & 0.03 & 0.04 & 0.01 & 0.01 \\
\hline $\mathrm{PbO}$ & $<0.07$ & 0.19 & 0.04 & 0.04 & $<0.07$ & 0.13 & b.d.l. & 0.03 & $<0.04$ & 0.07 & b.d.l. & 0.02 \\
\hline $\mathrm{Cr}_{2} \mathrm{O}_{3}$ & $<0.03$ & 0.03 & b.d.l. & 0.01 & $<0.03$ & 0.05 & b.d.l. & 0.01 & $<0.02$ & 0.02 & b.d.l. & 0.01 \\
\hline $\mathrm{TiO}_{2}$ & $<0.04$ & 0.05 & b.d.l. & 0.01 & $<0.04$ & 0.05 & b.d.l. & 0.01 & $<0.03$ & 0.04 & b.d.l. & 0.01 \\
\hline $\mathrm{CO}_{2}$ & 43.33 & 44.26 & 42.42 & 0.33 & 42.60 & 44.05 & 38.46 & 1.09 & 46.32 & 46.90 & 45.69 & 0.32 \\
\hline Total & 98.69 & 100.75 & 94.36 & 0.83 & 97.12 & 100.22 & 94.04 & 1.98 & 97.98 & 95.34 & 99.37 & 1.12 \\
\hline
\end{tabular}

Mesh cores are sometimes composed of both calcite (C2) and serpentine (e.g. fig. 6). These specific domains constitute places where calcite and serpentine formed together during peridotite serpentinization and carbonation.

The $\delta^{13} \mathrm{C}$ values for carbonates -5 to $+0.5 \%$ (the lowest values being related to $\mathrm{C} 2$ calcite) are comparable to the $\delta^{13} \mathrm{C}$ values recorded for total carbon in serpentinite exhibiting calcite veins at Lost-City hydrothermal field (Delacour et al., 2008) and at the Lost City-type hydrothermal system located at the magma-poor passive Iberian Margin (Klein et al., 2015), where seawater is involved. Eickmann et al. (2009a) reported $\delta^{18} \mathrm{O}$ values for calcite hosted serpentinite ranging between +10.3 to $+14.3 \%$ or for the Logatchev Hydrothermal Field and proposed comparable high temperature $(\sim$ $\left.129-186{ }^{\circ} \mathrm{C}\right)$ for calcite formation. The authors explained the negative $\delta^{13} \mathrm{C}$ values $(-5 \%$ ) as due to a mantle-derived carbon dioxide component. Interestingly, Eickmann et al. (2009a) proposed that the limited fluid renewal in a sub-closed system during mesh carbonation can be responsible for the concomitant $\delta^{13} \mathrm{C}$ decreasing and $\delta^{18} \mathrm{O}$ increasing. Furthermore, Alt et al. (2012) have shown that a small amount of a reduced $(-25 \%$ ) carbon mixed in with seawater can explain the $\mathrm{C}$ depleted composition for abyssal serpentinites resulting from low temperature peridotite alteration. Herein, the low values $\delta^{13} \mathrm{C}$ values for $\mathrm{C} 2$ carbonates could reflect this mixing between oceanic (inorganic) $\mathrm{C}$ and depleted $\mathrm{C}$ resulting from serpentinization itself (Fig. 11).

Considering a fluid dominated systems, our results support that carbonation of the Chenaillet serpentinites occurred at temperatures ranging between $110{ }^{\circ} \mathrm{C}$ and $180^{\circ} \mathrm{C}$.

\subsection{Genetic model for Chenaillet ophicalcite formation}

The Chenaillet ophiolitic complex has been interpreted to represent a well-preserved typical ocean floor segment from a slow spreading environment (Lagabrielle, 2009; Lagabrielle and Lemoine, 1997; Manatschal et al., 2011). The formation of oceanic core complexes in this extensional environment promotes fluid-rock interaction (Andreani et al., 2007; Rouméjon and Cannat, 2014). The present work supports a conceptual model for ophicalcite formation in this general framework (Fig. 13). Various factors such as tectonic stress (McCaig et al., 2007), thermal cracking (Boudier et al., 2005; Korenaga, 2007) or reaction-induced fracturing (Iyer et al., 2008; Okamoto and Shimizu, 2015; Plümper et al., 2012; Rudge et al., 2010), or most probably a combination of all these processes (Andreani et al., 2007; Rouméjon and Cannat, 2014) favor the increasing of rock permeability during rock exhumation to facilitate serpentinization. In oceanic setting, fluid-assisted alteration during exhumation of peridotite and gabbro along detachment fault leads to the development of a discrete cracking network that can considerably enhance fluid transport.

\subsubsection{Serpentinization during initial peridotite rock exhumation in an oceanic setting}

Major and trace elements compositions of the Chenaillet serpentinite and mafic bodies supports a depleted lherzolite protolith with few heterogeneities (Bertrand et al., 1987; Chalot-Prat et al., 2003; Lafay et al., 2013) and with characteristic low Al/Si ratio. Textures, 


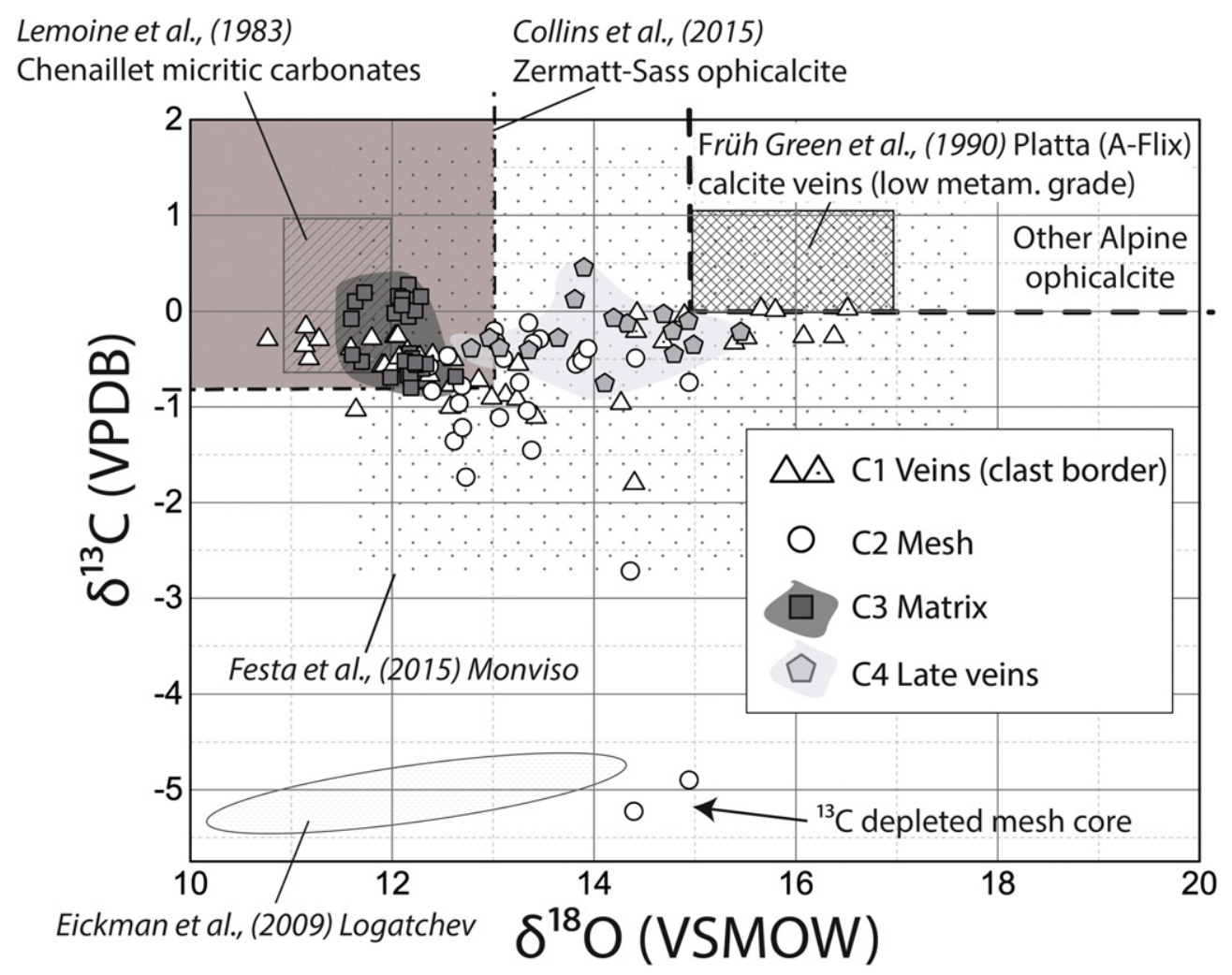

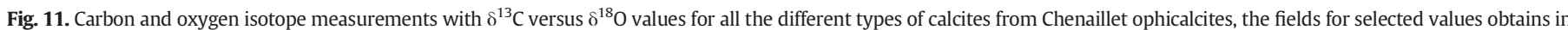
other alpine ophicalcite are also reported. The error of measurements is within the symbol size.

mineralogy and chemical signature support that prior to any carbonation, the Chenaillet peridotite experienced extensive serpentinization (Table 4). The Chenaillet serpentinite clasts within the ophicalcite breccia are most of the time characterized by a well-developed serpentine mesh resulting from olivine and orthopyroxene replacement (Figs. 2 and 4$)$.

The limited enrichment in fluid mobile elements recorded by the Chenaillet ophiolites when compared to serpentinite from mantle
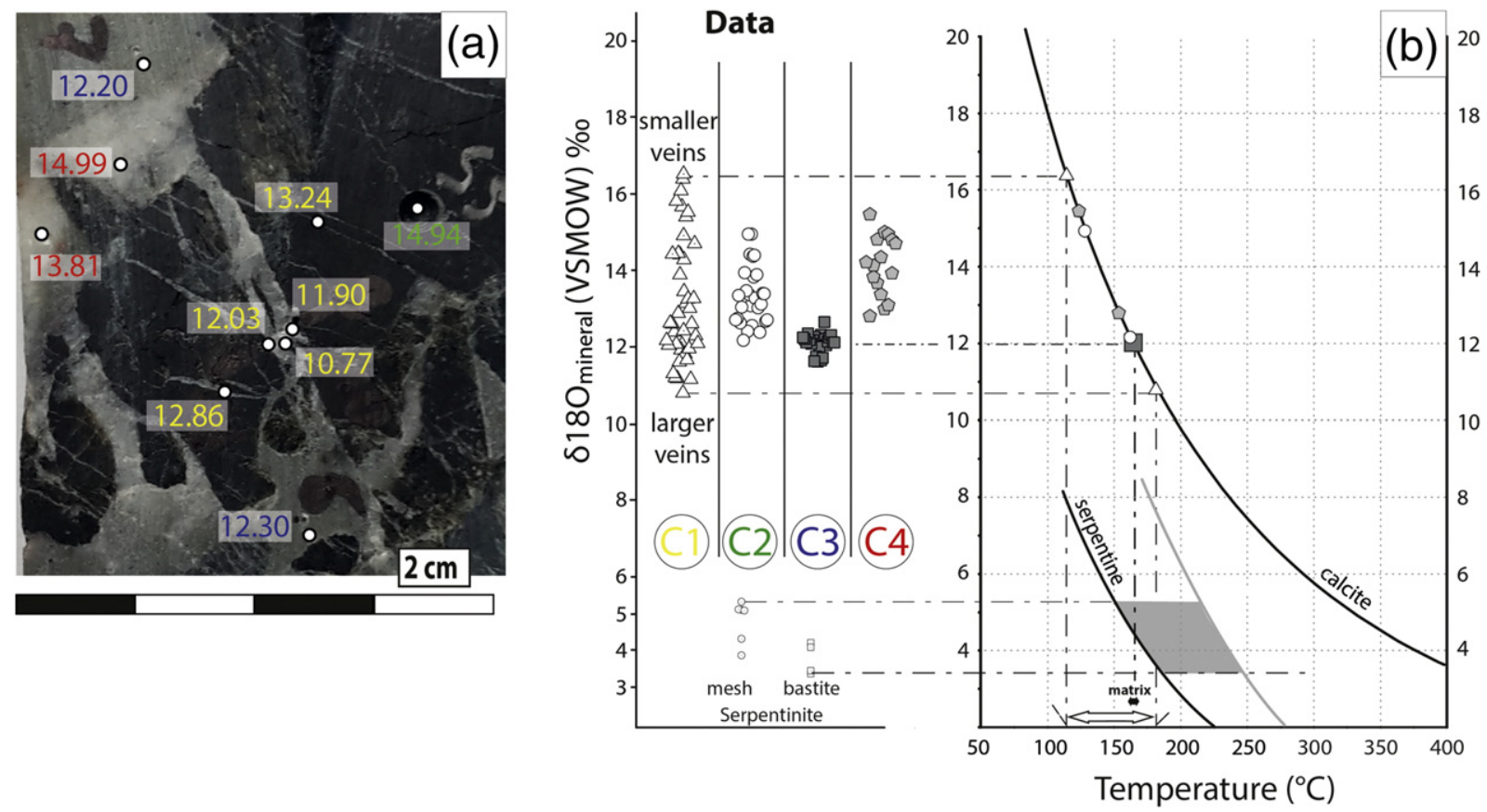

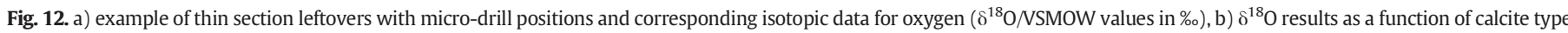

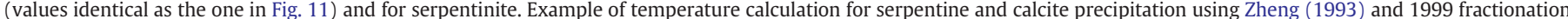

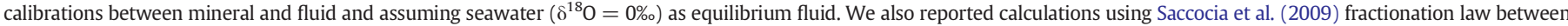

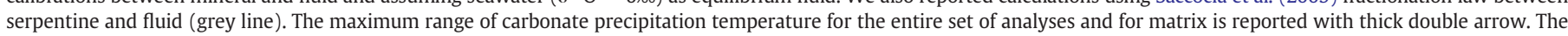
range for serpentine formation temperature is underline by grey area. The size of the symbols correspond to the error range. 
wedge or subduction zones (Deschamps et al., 2013), reinforces the hypothesis that Alpine metamorphic overprint was limited for this unit and that serpentinization occurred in an abyssal-type environment (Fig. 13) dominated by seawater interactions, similar to a slowspreading ridge environment (Dick et al., 2003; Kodolányi et al., 2011; Paulick et al., 2006) probably during sea-floor exhumation and cooling and amphibolitization of the unit (Mevel et al., 1978). This is independently confirmed by the meta carbonates from Lago Nero (SW of Chenaillet unit) at the top of ultramafic units that preserve isotopic signature typical for oceanic sediments of $\delta^{18} \mathrm{O} 20-30 \%$ (Lemoine et al., 1983).

We conclude that the minimum temperature for serpentinization in the Chenaillet unit was above $155^{\circ} \mathrm{C}$ (Fig. 12 and Table 2) and is related to the interaction of marine water with peridotite (Table 4). D-depletion in serpentinite seems to reflect the involvement of hydrogen, probably produced during serpentinization. Indeed, the oxidation of the iron component of olivine is known to produce $\mathrm{H}_{2}$ while ferric iron is trapped either by magnetite or by serpentine, especially at temperature below $200{ }^{\circ} \mathrm{C}$ (Klein et al., 2014). Magnetite was identified to nucleate and grow at mesh borders (e.g. Fig. 6) during mineral replacement (see also Evans, 2008; Evans et al., 2013). The Fe and Al component might favor the formation of polyhedral serpentine, or the lizarditechrysotile mixture, (Andreani et al., 2008) as observed in in this study within serpentinite mesh cores.

Chenaillet serpentinite and serpentinite clasts within ophicalcites are cpx-free or contain very small amounts of serpentinized clinopyroxene. However, note that alteration of diopside might have occurred at temperatures above $300{ }^{\circ} \mathrm{C}$ and chemical gradient as well as mass transfer can explain the lack of Ca-bearing minerals in serpentinite (Klein et al., 2013). Here, the hydration of clinopyroxene component might favor the liberation of aqueous Ca responsible for shallower carbonation.

\subsubsection{Onset of carbonation along veins following serpentinization}

The onset of calcite precipitation in veins (1st event in Fig. 13b and c) is recorded by the Chenaillet ophiolite as a continuation of intense serpentinization stage occurring at higher temperatures. Carbonate precipitation could have been driven down-temperature fluid flow, towards the surface or fluid decompression during fracturing and associated expansion, for example. At temperatures above $100{ }^{\circ} \mathrm{C}$, a rapid decompression of the fluid due to cracking will likely result in boiling. A decrease of fluid temperature will lead to an increase of $\mathrm{pH}$ (Bischoff and Seyfried, 1978). The experimental studies by Bischoff and Seyfried (1978) suggest that calcite precipitates upon cooling below $200{ }^{\circ} \mathrm{C}$. We calculated the concentrations of total Ca concentration in seawater in equilibrium with calcite using the software package SUPCRT (Johnson et al., 1992) together with the Slop98 data base (Sverjensky et al., 1997), and the software Soluble (Roselle and Baumgartner, 1995). In agreement with Bischoff and Seyfried (1978) we calculate a decrease in concentrations for calcium with decreasing temperature and also pressure (see Appendix), supporting the idea that calcite precipitated from fluids while flowing down temperature in response to a decrease in carbonate mineral solubility in agreement with Plummer and Busenberg (1982).

At temperature above $60{ }^{\circ} \mathrm{C}$, in carbonate hosted hydrothermal chimney, precipitation of aragonite is usually observed instead of calcite (e.g. Ludwig et al., 2006), likely due to kinetic inhibition of calcite precipitation. Nevertheless, calcite is predominantly described in veins in the basement of venting systems (Früh-Green et al., 2003; Kelley et al., 2005).The increasing in $\delta^{18} \mathrm{O}$ values from large to small calcite veins (Fig. 12) suggest that veining and calcite precipitation occurs during cooling of the ophicalcite while cracking spreads.

Gabbroic bodies' alteration by hydrothermal fluid circulation could represent a source of dissolved Ca for shallower carbonation as hydrothermal cells probably involve both ultramafic and intrusive bodies along large detachment fault (e.g. McCaig and Harris, 2012). However, the amount of gabbroic and albitite bodies in Chenaillet is small
(Cordey and Bailly, 2007; Manatschal et al., 2011; Mevel et al., 1978) and their emplacement is cogenetic with the troctolitic units (Li et al., 2013). Here we propose that the calcium contained in seawater itself is enough to precipitate carbonate at shallower depth.

\subsubsection{Pervasive carbonation}

We report that calcite cracks ( 1 st event) are intimately linked with a pervasive carbonation of ultramafic rocks occurring at ca. $130-150{ }^{\circ} \mathrm{C}$ (2nd event in Fig. 13b and c, and Table 4). We do not exclude that serpentine + calcite might locally have formed in equilibrium during transition from serpentinization to carbonation of mesh cores (Fig. 6). The complicated grain boundary of some calcite crystals in mesh textures suggests that olivine or pyroxene did react with fluids to form serpentine then calcite. Some textural features might reflect the replacement of serpentine by calcite (Figs. 6, 9b), despite the fact that serpentine replacement is slower than that of olivine in carbonated fluids at $200{ }^{\circ} \mathrm{C}$ (Hövelmann et al., 2011; Lafay et al., 2014). The carbonates display values for $\mathrm{Mn}, \mathrm{Mg}$ and Fe up to several hundred of ppm higher than those reported in calcite veins and other calcite occurrences (Tables 2 and 4). They have a low Sr content when compared to modern hydrothermal carbonates (calcite/aragonite) hosted in serpentinite (e.g. Ludwig et al., 2006). This suggests that the replacement processes were rock dominated.

Similar replacement features were observed in other ophicalcite localities (Clerc et al., 2014; Lavoie and Cousineau, 1995). The isotopic values are comparable to those reported here $(\sim+12.6-+13.8 \%$, Clerc et al., 2014). The authors proposed pervasive replacement of serpentine by calcite due to hot hydrothermal fluids in these rocks from the Pyrenees.

\subsubsection{Hydrothermal cementation: coupled carbonate and serpentine precipitation}

The breccia cement is volumetrically important but the absence of fossils and the textures we report suggests that the origin is not sedimentary. The majority of the breccia's observed are clast supported. The monogenic nature of the breccia's and presence of angular serpentinite clasts with sizes reaching several dozen of centimeter suggest a very small transports distance of the serpentinites debris, as one would observe in talus at the bottom of extensional faults (Fig. 13).

We propose a hydrothermal origin for these carbonates in the Chenaillet ophicalcite. Hydrothermal fluid decompression and cooling favored, enhanced by faulting within the seafloor, and cooling will lead to a decrease of calcite solubility (Simmons and Christenson, 1994; Zheng, 1990). The temperatures reported by the carbonate cement of $155^{\circ}-170^{\circ} \mathrm{C}$ would support boiling in a relatively shallow oceanic environment. Boiling could result in turbulent flow, resulting in the matrix-supported breccia's observed.

The co-precipitated chrysotile in the matrix carbonate further supports precipitation of matrix carbonates from a fluid. Chrysotile has nucleated and then radially grew into open space or loose calcite slurry (3-4th step in Fig. 13c). The small crystal size of matrix carbonates is atypical for hydrothermal carbonates, which are typically sparitic, as seen in the veins crosscutting clasts and matrix. The small crystal size, the roundish crystals all suggest that the matrix carbonate was rapidly precipitated in a high-energy fluid flow environment. Only a limited crystals coarsening was observed after calcite matrix precipitation (DeHoff, 1991) (Fig. 8b). Boiling will result in a large supersaturation of carbonate in the fluid. Carbon dioxide will preferentially be partitioned into the gas phase. $\mathrm{CO}_{2}$ degassing will in turn increase supersaturation of fluid with calcium (Pentecost, 1995) and account for massive calcite precipitation and cementation. Alternatively, this might also be possible by mixing ascending fluids with cold surface fluids. In any case, we argue that these ophicarbonates formed at the bottom of extensional faults, close to the seafloor, with or without boiling of fluids rapidly expelled from the faults (Fig. 13c). Hence, we 
proposed that the Chenaillet ophicalcites breccia constitute the end result of progressive peridotite basement alteration, brecciation and cementation (Fig. 13c).

Minimum temperature of formation of the serpentinites $\left(>155^{\circ} \mathrm{C}\right)$ is slightly higher than that obtained for carbonates, though carbonatization occurred over a temperature range of $110-180^{\circ} \mathrm{C}$ ). These temperature estimates are uncertain, since we assumed a water composition (unaltered ocean water) for all these calculations. We discretized changes of temperature or fluid composition throughout the formation of Chenaillet ophicalcite. The above temperatures ranges are comparable to the one reported in different peridotite hosted carbonates from midocean ridge (e.g. site 1268, 1271 (Alt et al., 2007; Bach et al., 2011) Atlantis massif (Boschi et al., 2008; Früh-Green et al., 2003) or Logatchev hydrothermal field (Eickmann et al., 2009a, 2009b).

Multiple hydrothermal events are involved to produce the amount of cement observed and-or a sustainable (sub)continuous
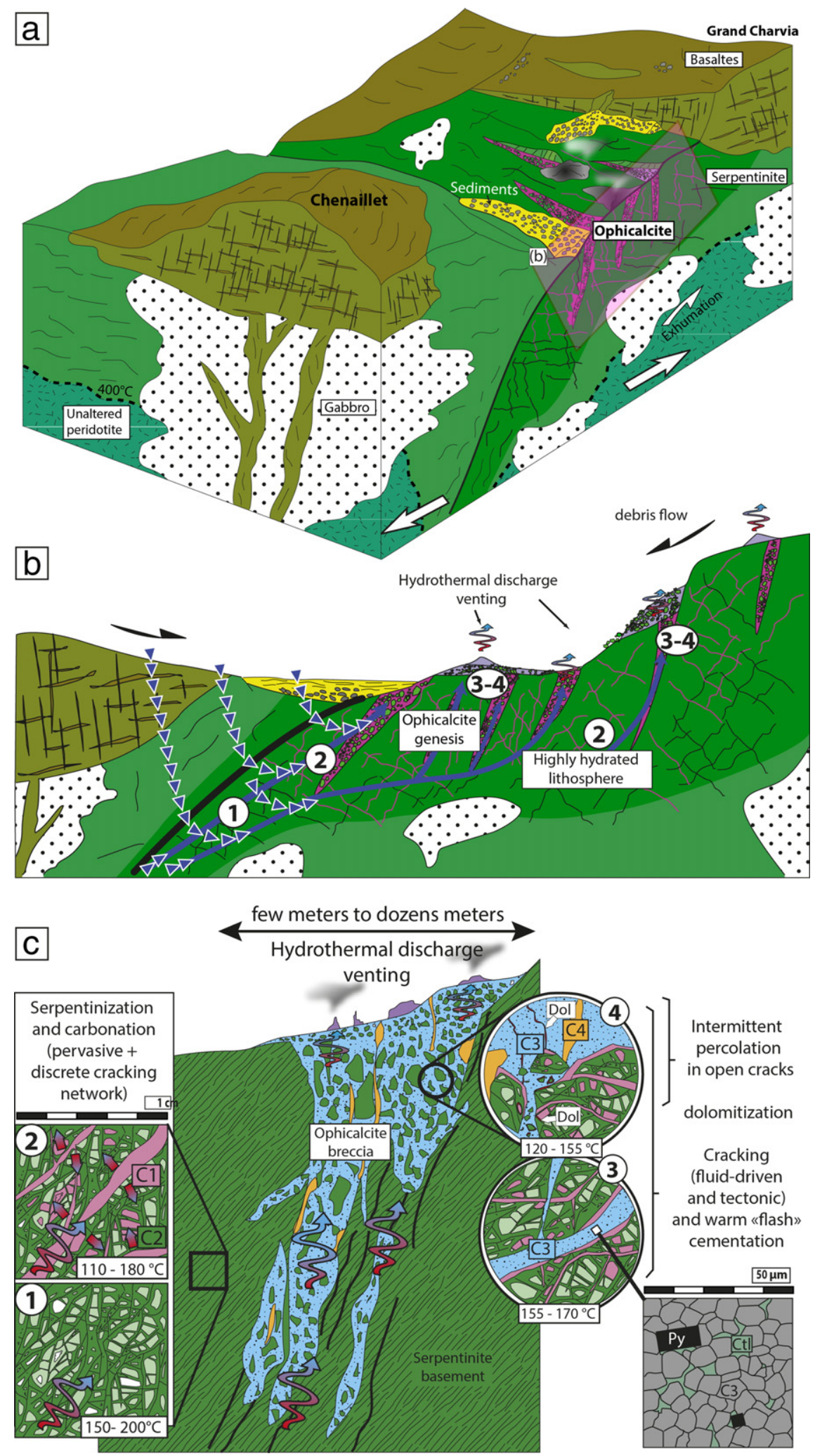
Table 4

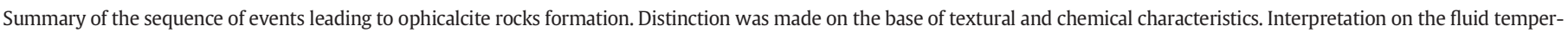
ature and the context of formation is reported (refer to text for more detail).

\begin{tabular}{|c|c|c|c|c|c|c|}
\hline \multirow[t]{2}{*}{ Type } & \multirow[t]{2}{*}{ Textural characteristics and Event } & & \multicolumn{2}{|l|}{ Chemical characteristic } & \multirow{2}{*}{$\begin{array}{l}\text { Equilibrium } \\
\text { fluid } \mathrm{T}\left({ }^{\circ} \mathrm{C}\right)\end{array}$} & \multirow[t]{2}{*}{ Geological meaning } \\
\hline & & & $\begin{array}{l}\text { Isotope } \\
\text { signatures }\end{array}$ & $\begin{array}{l}\text { Elemental } \\
\text { composition }\end{array}$ & & \\
\hline Serp. & $\begin{array}{l}\text { Mesh and bastite serpentinite } \\
\text { texture }\end{array}$ & Early serpentinization & $\begin{array}{l}3.3<\delta^{18} \mathrm{O}<5.5 \% \\
-133<\delta \mathrm{D}<-148 \%\end{array}$ & $\begin{array}{l}\mathrm{Mg} \# \approx 0.94 \\
\text { Mesh core } \\
\text { enriched in } \mathrm{Al}\end{array}$ & $>155$ & $\begin{array}{l}\text { Pervasive and channeled } \\
\text { serpentinization after olivine in active } \\
\text { ocean floor system at moderate } \\
\text { temperature and with D depleted fluid }\end{array}$ \\
\hline $\mathrm{C} 1$ & $\begin{array}{l}\text { Dense calcite microcracks } \\
\text { network }\end{array}$ & $\begin{array}{l}\text { Micro-fracturing of serpentinite } \\
\text { and onset of carbonation }\end{array}$ & $\begin{array}{l}10.7<\delta^{18} \mathrm{O}<16.5 \% \\
-1.8<\delta^{13} \mathrm{C}<0 \%\end{array}$ & $\begin{array}{l}\mathrm{MgO} \approx 0.20 \mathrm{wt} \% \\
\mathrm{MnO} \approx 0.09 \mathrm{wt} \% \\
\mathrm{SrO} \approx 0.04 \mathrm{wt} \%\end{array}$ & $110-180$ & $\begin{array}{l}\text { Carbonation in tectonically active brittle } \\
\text { system. Channelization of fluid and } \\
\text { limited fluid-flow. Contemporaneous to }\end{array}$ \\
\hline $\mathrm{C} 2$ & $\begin{array}{l}\text { Serpentinite mesh core } \\
\text { replaced by calcite }\end{array}$ & $\begin{array}{l}\text { Pervasive carbonation of } \\
\text { serpentinite }\end{array}$ & $\begin{array}{l}12.2<\delta^{18} \mathrm{O}<15 \% \\
-5.2<\delta^{13} \mathrm{C}<-0.1 \%\end{array}$ & $\begin{array}{l}\text { Mg and Mn } \\
\text { enrichment }\end{array}$ & $130-160$ & $\begin{array}{l}\text { rock impregnation by }>110^{\circ} \mathrm{C} \text { fluid } \\
\text { enriched in carbonate component }\end{array}$ \\
\hline C3 & $\begin{array}{l}\text { Serpentinite clasts within small } \\
\text { calcite grain matrix and chrysotile }\end{array}$ & $\begin{array}{l}\text { Individualization of clasts and } \\
\text { matrix precipitation }\end{array}$ & $\begin{array}{l}\delta^{18} \mathrm{O} \approx 12 \% \\
\delta^{13} \mathrm{C} \approx 0 \%\end{array}$ & $\begin{array}{l}\text { Sr enrichment } \\
\text { Chrysotile } \\
\mathrm{Mg} \# \approx 0.97\end{array}$ & $155-170$ & $\begin{array}{l}\text { Brecciation by hydro-fracturing and fast } \\
\text { and intense fractured filled cementation } \\
\text { in a warm }\left(\approx 160{ }^{\circ} \mathrm{C}\right) \text { fluid-dominated } \\
\text { system }\end{array}$ \\
\hline C4 & $\begin{array}{l}\text { Sparitic micrometric to centimetric } \\
\text { calcite veins crosscutting matrix }\end{array}$ & $\begin{array}{l}\text { Cracking of ophicalcite } \\
\text { and calcite vein formation }\end{array}$ & $\begin{array}{l}12.8<\delta^{18} \mathrm{O}<15.8 \% \\
\delta^{13} \mathrm{C} \approx 0 \%\end{array}$ & & $120-155$ & $\begin{array}{l}\text { Late fracturing and recrystallization of } \\
\text { calcite favored by tectonic activity } \\
\text { and/or hydrofracturing pulse }\end{array}$ \\
\hline Dol & $\begin{array}{l}\text { idiomorphic dolomite at } \\
\text { calcite-serpentine interface }\end{array}$ & $\begin{array}{l}\text { Equilibration and } \\
\text { crystallization } \\
\text { of metamorphic dolomite }\end{array}$ & & $\begin{array}{l}\mathrm{MnO} \approx 0.19 \mathrm{wt} \% \\
\mathrm{SrO} \approx 0.03 \mathrm{wt} \%\end{array}$ & & $\begin{array}{l}\text { Equilibration between serpentine and } \\
\text { calcite forming dolomite front }\end{array}$ \\
\hline
\end{tabular}

hydrothermal circulation within serpentinite basement, characteristic for some modern mid-ocean hydrothermal sites (Früh-Green et al., 2003; Ludwig et al., 2011; Schwarzenbach et al., 2013). The (co)precipitation of chrysotile instead of lizardite or lizardite \pm chrysotile may have been favored by a local increase of dissolved species in the fluid (Grauby et al., 1998; Normand et al., 2002) due to serpentine dissolution during carbonation. Fluid probably contained few $\mathrm{Al}$ and ferric iron as these components favor the formation of lizardite (O'Hanley et al., 1989). Alternatively, the lower temperature during matrix formation, with respect to serpentinization, might also be responsible for chrysotile stabilization. The source of $\mathrm{Mg}$ and $\mathrm{Si}$ for chrysotile could come from local water-rock interaction, or from these elements might have been leached upstream from the reaction site.

\subsubsection{Maintained fluid circulation}

Ophicalcite cement is cross-cut by non-hierarchical cracks filled by coarse calcite sometimes connected to clasts (4th event in Fig.13c, Table 4). Most of the veins show multistep histories with successive infillings of calcite. These veins attest to late fracturing and episodic fluid flow $\left(120-150{ }^{\circ} \mathrm{C}\right)$ even after clasts cementation. This was also noted by Bernoulli and Weissert (1985), who proposed that, in the Totalp unit, repeated fracturing could have induced punctual dilatation of the host rock, which caused the influx of fluids, possibly under hydrothermal conditions. Traces of this hydrothermal circulation at detachment surface is marked in modern environments by venting and cemented mounds (Tucholke et al., 2013). Herein breccia may have been formed in zone of intense alteration in the stockwork of open hydrothermal systems beneath vent and massive sulfide deposit (e.g. Hannington et al., 1995). The heat source can be maintained by episodic magmatic intrusions inside detachment system. Episodic warm fluid injection and pressure assisted fragmentation may account for clasts distribution within matrix and late veins distribution. Katz et al. (2006) indicated that fast cementation appearing nearly after cracking and breccia collapse may lead to similar features in compressional systems. Herein, ophicalcite breccia formation processes could be seen in the same way in the frame of detachment systems (Fig. 13c) with evolving fluids circulation (McCaig et al., 2007).

Other studies have reported isotopic values for internal sediment and fracture-filling cement in Alpine and Appenine ultramafic samples (Barbieri et al., 1979; Festa et al., 2015; Früh-Green et al., 1990; Weissert and Bernoulli, 1984 among others). Recent studies from nearby Monviso ophicalcites (Festa et al., 2015) report $\delta^{18} \mathrm{O}$ bulk values ranging from 11.8 and $17.8 \%$ in carbonates (Fig. 11). Based on accurate petrographic-mapping and paleogeographic reconstructions the authors propose that ophicalcites where parts of an ancient core complex and that these values reflect early-oceanic alteration at low temperature $\left(100<\mathrm{T}<150{ }^{\circ} \mathrm{C}\right)$ which was preserved through the Alpine eclogite metamorphism. Ophicarbonates and Northern Apennine exhibit also preserved volumes of meta-ultramafic away from zones of intense deformation. Previous studies in northern Apennine have conclude that carbonate hosted fractured serpentinite recorded a polyphase alteration and reworking history and point a hydrothermal genesis during ocean spreading (Treves and Harper, 1994). More recently, Schwarzenbach et al. (2013) draw the similarities between Atlantis massif and north Apenine alteration where long lived serpentinization along detachment faulting take place at temperatures of ca. $200 \pm 50{ }^{\circ} \mathrm{C}$ and carbonation at temperatures below $150{ }^{\circ} \mathrm{C}\left(\delta^{18} \mathrm{O}\right.$ with a range between +12.7 and $+24 \%$ for calcite). Collins et al. (2015), reported $\delta^{18} \mathrm{O}$ values ranging between $+9 \%$ and $+13 \%$ o for ophicalcite from Zermatt-Saas unit. Some of the ophicalcites have very similar textures and the lower $\delta^{18} \mathrm{O}$

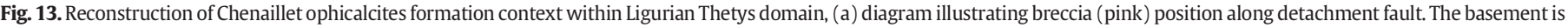

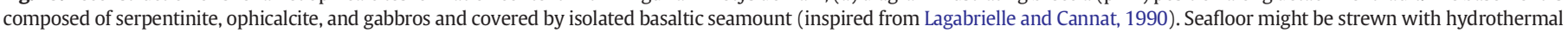

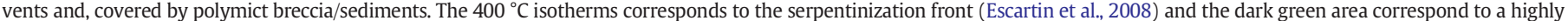

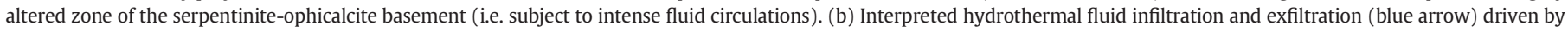

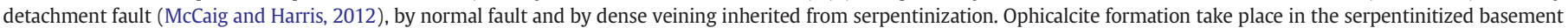

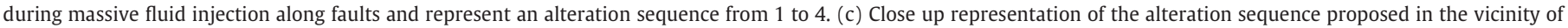

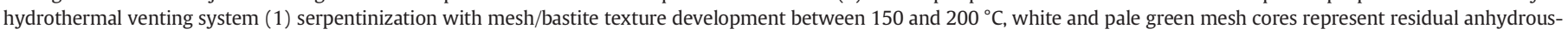

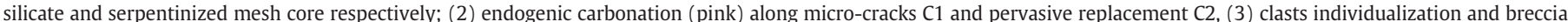

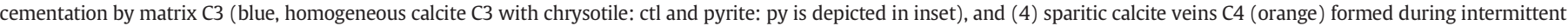

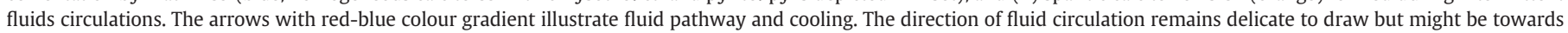
surface. The top of the altered zone is also constituted of cemented serpentinite debris and can be capped by lithified carbonates and carbonates Chimney (e.g. Los City system). 
values were possibly acquired during high temperature seawater related hydrothermal alteration. Früh-Green et al. (1990) proposed a multistep hydrothermal alteration during the early Alpine history, affecting ophicarbonates in the South Pennine Platta nappe and in the Arosa Zone, to explain ophicalcite formation at high temperature (100-150 ${ }^{\circ} \mathrm{C}$ ) in a tectonic wedge system. However, as explained above, based on our textural observations and the diffusion data for oxygen and manganese (which diffuse faster than oxygen in carbonate (Müller et al., 2012)) we infer that calcite preserved its original, oceanic, oxygen isotope composition.

5.2.5.1. Dolomitization. Conventional and CL petrography reveal the formation of dolomite which have not yet been described in previous studies of the Chenaillet ophicalcite (Fig. 8 and 4th event in Fig. 13c). Lavoie and Cousineau (1995) reports the coeval presence of rare dolomite and calcite filling voids in ophicalcite from Québec (Appalachians) without further discussions. Dolomite is especially present in micro-breccia and/or finely layered brecciated zones. Dolomite habitus consists mainly of idiomorphic crystals formed within serpentine at serpentinite-clast edge, and, as veinlets in calcitic matrix. Based on these textural features we propose that dolomite crystallization is mainly marked by the concomitant dissolution of serpentine and calcite, indicating a reaction between serpentine and calcite. Moreover, dolomite veinlets crosscutting cement (Fig. 9a) indicate that dolomite (over-) saturation is reached, possibly in response to serpentine dissolution.

However, considering a recent experimental investigation on peridotite carbonation after serpentinization at $300{ }^{\circ} \mathrm{C}$ (Grozeva et al., 2017), we do not exclude that dolomite can be formed through carbonation of residual olivine, pyroxene or brucite during $\mathrm{CO}_{2}$ rich fluid circulation. The $\mathrm{Sr}$ concentration in dolomite of about $200 \mathrm{ppm}$ (Table 2) is in agreement with dolomite forming in equilibrium with a seawater-like component (Banner and Hanson, 1990).

\section{Conclusions}

Detailed fieldwork, together with petrographic and geochemical information of the Chenaillet unit ophicalcite allowed the processes of serpentinization and carbonation of ultramafic rocks to be evaluated. Initial serpentinitization during early exhumation towards the seafloor was followed by several periods of carbonation of the serpentinites and their relict mineralogy. Carbonate precipitated in veins during several fracturing periods and micritic matrix carbonates surrounding clasts can be texturally and chemically distinguished.

Carbonation initiates in brittle domains with a discrete calcite vein networks characterized by a wide range of isotopic composition (10.5< $\delta^{18} \mathrm{O}<16.5 \%$ ). Both serpentine and likely primary anhydrous silicate reacts and participates in the formation of calcite in the serpentine mesh textures.

The micritic matrix is the result of fluids escaping along extensional faults towards the surface. Carbonate is precipitated either due to mixing with cold surface fluids, or by local boiling. This is supported by the fact that we observe some matrix supported breccia's, the small grain size of the precipitated carbonates, and the fact that we estimate temperatures of precipitation superior to $150{ }^{\circ} \mathrm{C}$. The geochemical data presented here, along with the petrographic observations are similar to those observed in the Lost City or Logatchev environment (e.g. Früh-Green et al., 2003; Ludwig et al., 2011 Eickmann et al., 2009a, 2009b). Also some ophicarbonates from the Western Alps north Apennine have similar characteristics, which were considered as paleo-stockworks of a hydrothermal system analogs to modern hydrothermal field (Bernoulli et al., 1985, Collins et al., 2015, Festa et al., 2015, Treves and Harper, 1994, Schwarzenbach et al., 2013).

\section{Acknowledgements}

The authors are grateful to Yves Lagabrielle for his expert comments and our exchanges prior to submission. The authors appreciate the helpful comments of the two anonymous reviewers and editor-in-chief Marco Scambelluri. We acknowledge technical support from Nathaniel Findling, Pierre Vonlanthen and Valentina Batanova for X-ray powder diffraction analysis, SEM analyses and microprobe measurements respectively. We greatly thanks Benita Putlitz for help during serpentinite ${ }^{18} \mathrm{O}$ measurements. We also thanks Susanne Seitz for helps during microprobe measurements session and Othmar Müntener and Alexei Ulianov for the unrestricted access to the Raman spectroscopy laboratory and Peter Baumgartner and Claudia Baumgartner for the access to the cathodoluminescence laboratory. Funding to Lukas P. Baumgartner in the form of the SNF is acknowledged.

\section{Appendix A. Supplementary data}

Supplementary data to this article can be found online at https://doi. org/10.1016/j.lithos.2017.10.006.

\section{References}

Agard, P., Monié, P., Jolivet, L., Goffé, B., 2002. Exhumation of the Schistes Lustrés complex: in situ laser probe $40 \mathrm{Ar} / 39 \mathrm{Ar}$ constraints and implications for the Western Alps. J. Metamorph. Geol. 20, 599-618.

Agrinier, P., Javoy, M., Girardeau, J., 1988. Hydrothermal activity in a peculiar oceanic ridge: Oxygen and hydrogen isotope evidence in the Xigaze ophiolite (Tibet China). Chem. Geol. 71 (4).

Allen, D.E., Seyfried, W., 2004. Serpentinization and heat generation: constraints from Lost City and Rainbow hydrothermal systems. Geochim. Cosmochim. Acta 68, 1347-1354

Alt, J.C., Shanks, W.C., Bach, W., Paulick, H., Garrido, C.J., Beaudoin, G., 2007. Hydrotherma alteration and microbial sulfate reduction in peridotite and gabbro exposed by detachment faulting at the Mid-Atlantic Ridge, $15^{\circ} 20^{\prime} \mathrm{N}$ (ODP Leg 209): a sulfur and oxygen isotope study. Geochem. Geophys. Geosyst. 8.

Alt, J.C., Shanks, W., Crispini, L., Gaggero, L., Schwarzenbach, E.M., Früh-Green, G.L., Bernasconi, S.M., 2012. Uptake of carbon and sulfur during seafloor serpentinization and the effects of subduction metamorphism in Ligurian peridotites. Chem. Geol. 322 268-277.

Andreani, M., Mével, C., Boullier, A., Escartin, J., 2007. Dynamic control on serpentine crystallization in veins: constraints on hydration processes in oceanic peridotites. Geochem. Geophys. Geosyst. 8.

Andreani, M., Grauby, O., Baronnet, A., Muñoz, M., 2008. Occurrence, composition and growth of polyhedral serpentine. Eur. J. Mineral. 20, 159-171.

Bach, W., Rosner, M., Jöns, N., Rausch, S., Robinson, L.F., Paulick, H., Erzinger, J., 2011. Carbonate veins trace seawater circulation during exhumation and uplift of mantle rock: results from ODP Leg 209. Earth Planet. Sci. Lett. 311, 242-252.

Banner, J.L., Hanson, G.N., 1990. Calculation of simultaneous isotopic and trace element variations during water-rock interaction with applications to carbonate diagenesis. Geochim. Cosmochim. Acta 54, 3123-3137.

Barbieri, M., Masi, U., Tolomeo, L. 1979. Stable isotope evidence for a marine origin of ophicalcites from the north-central Apennines (Italy). Mar. Geol. 30, 193-204.

Barrett, T., Spooner, E., 1977. Ophiolitic breccias associated with allochthonous oceanic crustal rocks in the East Ligurian Apennines, Italy-a comparison with observations from rifted oceanic ridges. Earth Planet. Sci. Lett. 35, 79-91.

Bernoulli, D., 1974. Alpine Mediterranean and Central Atlantic Mesozoic Facies in Relation to the Early Evolution of the Tethys.

Bernoulli, D., Weissert, H., 1985. Sedimentary fabrics in Alpine ophicalcites, south Pennine Arosa zone, Switzerland. Geology 13, 755-758.

Bertrand, J., Courtin, B., Vuagnat, M., 1982. Elaboration d'un secteur de lithosphère océanique liguro-piémontais d'après les données de l'ophiolite du Montgenèvre (Hautes-Alpes, France et province de Turin, Italie). Ofioliti 7, 155-196.

Bertrand, J., Dietrich, V., Nievergelt, P., Vuagnat, M., 1987. Comparative major and trace element geochemistry of gabbroic and volcanic rock sequences, Montgenèvre ophiolite, Western Alps. Schweiz. Mineral. Petrogr. Mitt. 67, 147-169.

Bischoff, J.L., Seyfried, W.E., 1978. Hydrothermal chemistry of seawater from 25 degrees to 350 degrees C. Am. J. Sci. 278, 838-860.

Blackman, D.K., Karson, J.A., Kelley, D.S., Cann, J.R., Früh-Green, G.L., Gee, J.S., Hurst, S.D John, B.E., Morgan, J., Nooner, S.L., 2002. Geology of the Atlantis Massif (Mid-Atlantic Ridge, $30 \mathrm{~N}$ ): implications for the evolution of an ultramafic oceanic core complex. Mar. Geophys. Res. 23, 443-469.

Bonatti, E., Emiliani, C., Ferrara, G., Honnorez, J., Rydell, H., 1974. Ultramafic-carbonate breccias from the equatorial Mid Atlantic Ridge. Mar. Geol. 16, 83-102.

Bonatti, E., Lawrence, J.R., Morandi, N., 1984. Serpentinization of oceanic peridotites: temperature dependence of mineralogy and boron content. Earth Planet. Sci. Lett. 70, 88-94.

Bortolotti, V., Passerini, P., 1970. Magmatic activity. Sediment. Geol. 4, 599-624.

Boschi, C., Früh-Green, G.L., Delacour, A., Karson, J.A., Kelley, D.S., 2006. Mass transfer and fluid flow during detachment faulting and development of an oceanic core complex, Atlantis Massif (MAR 30 N). Geochem. Geophys. Geosyst. 7. 
Boschi, C., Dini, A., Früh-Green, G.L., Kelley, D.S., 2008. Isotopic and element exchange during serpentinization and metasomatism at the Atlantis Massif (MAR $30 \mathrm{~N}$ ): insights from B and Sr isotope data. Geochim. Cosmochim. Acta 72, 1801-1823.

Boudier, F., Nicolas, A., Mainprice, D., 2005. Does anisotropy of thermal contraction control hydrothermal circulation at the moho level below fast spreading oceanic ridges? Int. Geol. Rev. 47, 101-112.

Boudier, F., Baronnet, A., Mainprice, D., 2010. Serpentine mineral replacements of natural olivine and their seismic implications: oceanic lizardite versus subduction-related antigorite. J. Petrol. 51, 495-512.

Caby, R., 1995. Plastic deformation of gabbros in a slow-spreading Mesozoic ridge: example of the Montgenevre ophiolite, Western Alps. Mantle and Lower Crust Exposed in Oceanic Ridges and in Ophiolites. Springer, pp. 123-145.

Cannat, M., Sauter, D., Mendel, V., Ruellan, E., Okino, K., Escartin, J., Combier, V., Baala, M., 2006. Modes of seafloor generation at a melt-poor ultraslow-spreading ridge. Geology 34, 605-608.

Cannat, M., Fontaine, F., Escartin, J., 2010. Serpentinization and associated hydrogen and methane fluxes at slow spreading ridges. Divers. Hydrothermal Syst. Slow Spreading Ocean Ridges. 188, pp. 241-264.

Cashman, K.V., Ferry, J.M., 1988. Crystal size distribution (CSD) in rocks and the kinetics and dynamics of crystallization. Contrib. Mineral. Petrol. 99, 401-415.

Chalot-Prat, F., Bourlier, E.C.-Y., 2005. L'ophiolite du Chenaillet (Montgenèvre, Alpes franco-italiennes), témoin d'un segment de ride volcanique axiale d'un océan à croissance lente. Géol. Fr.

Chalot-Prat, F., Ganne, J., Lombard, A., 2003. No significant element transfer from the oceanic plate to the mantle wedge during subduction and exhumation of the Tethys ithosphere (Western Alps). Lithos 69, 69-103.

Charlou, J., Donval, J., Fouquet, Y., Jean-Baptiste, P., Holm, N., 2002. Geochemistry of high $\mathrm{H}_{2}$ and $\mathrm{CH}_{4}$ vent fluids issuing from ultramafic rocks at the Rainbow hydrotherma field ( $36^{\circ} 14^{\prime}$ N, MAR). Chem. Geol. 191, 345-359.

Clerc, C., Boulvais, P., Lagabrielle, Y., de Saint Blanquat, M., 2014. Ophicalcites from the northern Pyrenean belt: a field, petrographic and stable isotope study. Int. J. Earth Sci. 103, 141-163.

Collins, N.C., Bebout, G.E., Angiboust, S., Agard, P., Scambelluri, M., Crispini, L., John, T., 2015. Subduction zone metamorphic pathway for deep carbon cycling: II. Evidence from HP/UHP metabasaltic rocks and ophicarbonates. Chem. Geol. 412, $132-150$

Cordey, F., Bailly, A., 2007. Alpine ocean seafloor spreading and onset of pelagic sedimentation: new radiolarian data from the Chenaillet-Montgenèvre ophiolite (French-Italian Alps). Geodin. Acta 20, 131-138.

Cressey, B. 1979. Electron microscopy of serpentinite textures. Can. Mineral. 17, $741-756$

Dal Piaz, G., Ernst, W., 1978. Areal geology and petrology of eclogites and associated metabasites of the Piemonte ophiolite nappe, breuil-st. Jacques area, Italian Western Alps. Tectonophysics 51, 99-126.

Decitre, S., Deloule, E., Reisberg, L., James, R., Agrinier, P., Mével, C., 2002. Behavior of Li and its isotopes during serpentinization of oceanic peridotites. Geochem. Geophys. Geosyst. 3, 1-20.

DeHoff, R., 1991. A geometrically general theory of diffusion controlled coarsening. Acta Metall. Mater. 39, 2349-2360.

Delacour, A., Früh-Green, G.L., Bernasconi, S.M., Schaeffer, P., Kelley, D.S., 2008, Carbon geochemistry of serpentinites in the Lost City Hydrothermal System $\left(30^{\circ} \mathrm{N}, \mathrm{MAR}\right)$ Geochim. Cosmochim. Acta 72, 3681-3702.

Demény, A., Vennemann, T., Koller, F., 2007. Stable isotope compositions of the Penninic ophiolites of the Kõszeg-Rechnitz series. Cent. Eur. Geol. 50:29-46. https://doi.org/ 10.1556/CEuGeol.50.2007.1.3.

Denny, A.R., Kelley, D.S., Früh-Green, G.L., 2016. Geologic evolution of the Lost City Hydrothermal Field. Geochem. Geophys. Geosyst. 17, 375-394.

Deschamps, F., Godard, M., Guillot, S., Hattori, K., 2013. Geochemistry of subduction zone serpentinites: a review. Lithos $178,96-127$

Dick, H.J., Lin, J., Schouten, H., 2003. An ultraslow-spreading class of ocean ridge. Nature 426, 405-412.

Eberl, D., Drits, V., Srodon, J., 1998. Deducing growth mechanisms for minerals from the shapes of crystal size distributions. Am. J. Sci. 298, 499-533.

Eickmann, B., Bach, W., Peckmann, J., 2009a. Authigenesis of carbonate minerals in modern and Devonian ocean-floor hard rocks. J. Geol. 117, 307-323.

Eickmann, B., Bach, W., Rosner, M., Peckmann, J., 2009b. Geochemical constraints on the modes of carbonate precipitation in peridotites from the Logatchev Hydrotherma Vent Field and Gakkel Ridge. Chem. Geol. 268, 97-106.

Escartín, J., Smith, D.K., Cann, J., Schouten, H., Langmuir, C.H., Escrig, S., 2008. Central role of detachment faults in accretion of slow-spreading oceanic lithosphere. Nature 455 $790-794$

Evans, B., 2004. The serpentinite multisystem revisited: chrysotile is metastable. Int. Geol. Rev. 46, 479-506.

Evans, B.W., 2008. Control of the products of serpentinization by the $\mathrm{Fe} 2+\mathrm{Mg}-1$ exchange potential of olivine and orthopyroxene. J. Petrol. 49, 1873-1887.

Evans, K., Powell, R., Frost, B., 2013. Using equilibrium thermodynamics in the study of metasomatic alteration, illustrated by an application to serpentinites. Lithos 168 , $67-84$

Farver, J.R., 1994. Oxygen self-diffusion in calcite: dependence on temperature and water fugacity. Earth Planet. Sci. Lett. 121, 575-587.

Festa, A., Balestro, G., Dilek, Y., Tartarotti, P., 2015. A Jurassic oceanic core complex in the high-pressure Monviso ophiolite (western Alps, NW Italy). Lithosphere 7. 646-652.

Fisher, D., Byrne, T., 1990. The character and distribution of mineralized fractures in the Kodiak Formation, Alaska: implications for fluid flow in an underthrust sequence. J. Geophys. Res. Solid Earth 95, 9069-9080 (1978-2012).
Frost, B.R., 1985. On the stability of sulfides, oxides, and native metals in serpentinite. J. Petrol. 26, 31-63.

Früh-Green, G.L., Weissert, H., Bernoulli, D., 1990. A multiple fluid history recorded in Alpine ophiolites. J. Geol. Soc. 147, 959-970.

Fruh-Green, G.L., Scambelluri, M., Vallis, F., 2001. O-H isotope ratios of high pressure ultramafic rocks: implications for fluid sources and mobility in the subducted hydrous mantle. Contrib. Mineral. Petrol. 141, 145-159.

Früh-Green, G.L., Kelley, D.S., Bernasconi, S.M., Karson, J.A., Ludwig, K.A., Butterfield, D.A Boschi, C., Proskurowski, G., 2003. 30,000 years of hydrothermal activity at the Lost City vent field. Science 301, 495-498.

Gianelli, G., Principi, G., 1977. Northern Apennine ophiolite; an ancient transcurrent fault zone. Boll. Soc. Geol. Ital. 96, 53-58.

Goffé, B., Schwartz, S., Lardeaux, J.-M., Bousquet, R., 2004. Metamorphic structure of the Western and Ligurian Alps. Mitt. Österr. Min. Ges. 149, 125-144.

Grauby, O., Baronnet, A., Devouard, B., Schoumacker, K., Demirdjian, L., 1998. The chrysotilepolygonal serpentine-lizardite suite synthesized from a 3MgO-2SiO2-excess $\mathrm{H} 2 \mathrm{O}$ gel. Presented at the 7th International Symposium on Experimental Mineralogy, Petrology, and Geochemistry, Orléans, Abstracts. Terra Nova 24 (supplement).

Groppo, C., Rinaudo, C., Cairo, S., Gastaldi, D., Compagnoni, R., 2006. Micro-Raman spectroscopy for a quick and reliable identification of serpentine minerals from ultramafics. Eur. J. Mineral. 18, 319-329.

Grozeva, N.G., Klein, F., Seewald, J.S., Sylva, S.P., 2017. Experimental study of carbonate formation in oceanic peridotite. Geochim. Cosmochim. Acta 199, 264-286.

Haggerty, J.A., 1991. Evidence from fluid seeps atop serpentine seamounts in the Mariana Forearc: clues for emplacement of the seamounts and their relationship to forearc tectonics. Mar. Geol. 102, 293-309.

Hannington, M.D., Jonasson, I.R., Herzig, P.M., Petersen, S., 1995. Physical and chemical processes of seafloor mineralization at mid-ocean ridges. Seafloor Hydrothermal Syst. Phys. Chem. Biol. Geol. Interact. 115-157.

Higgins, M.D., 2000. Measurement of crystal size distributions. Am. Mineral. 85, 1105-1116.

Hövelmann, J., Austrheim, H., Beinlich, A., Munz, I.A., 2011. Experimental study of the carbonation of partially serpentinized and weathered peridotites. Geochim. Cosmochim. Acta 75, 6760-6779.

Ildefonse, B., Blackman, D., John, B., Ohara, Y., Miller, D., MacLeod, C., 2007. Oceanic core complexes and crustal accretion at slow-spreading ridges. Geology 35, 623-626.

Iyer, K., Austrheim, H., John, T., Jamtveit, B., 2008. Serpentinization of the oceanic lithosphere and some geochemical consequences: Constraints from the Leka Ophiolite Complex, Norway. Chem. Geol. 249:66-90. https://doi.org/10.1016/ j.chemgeo.2007.12.005.

Johnson, J.W., Oelkers, E.H., Helgeson, H.C., 1992. SUPCRT92: A software package for calculating the standard molal thermodynamic properties of minerals, gases, aqueous species, and reactions from 1 to 5000 bar and 0 to 1000 C. Comput. Geosci. 18, 899-947.

Kaseman, S., Meixner, A., Rocholl, A., Vennemann, T., Rosner, M., Schmitt, A.K., Wiedenbeck, M., 2001. Boron and oxygen isotope composition of certified reference materials NIST SRM 610/612 and reference materials JB-2 and JR-2. Geostand. Geoanal. Res. 25, 405-416.

Katz, D.A., Eberli, G.P., Swart, P.K., Smith Jr., L.B., 2006. Tectonic-hydrothermal brecciation associated with calcite precipitation and permeability destruction in Mississippian carbonate reservoirs, Montana and Wyoming. AAPG Bull. 90, 1803-1841.

Kelley, D.S., Karson, J.A., Blackman, D.K., FruÈh-Green, G.L., Butterfield, D.A., Lilley, M.D., Olson, E.J., Schrenk, M.O. Roe, K.K., Lebon, G.T. 2001. An off-axis hydrothermal vent field near the Mid-Atlantic Ridge at 30 N. Nature 412, 145-149.

Kelley, D.S., Karson, J.A., Früh-Green, G.L., Yoerger, D.R., Shank, T.M., Butterfield, D.A., Hayes, J.M., Schrenk, M.O., Olson, E.J., Proskurowski, G., 2005. A serpentinite-hosted ecosystem: the Lost City hydrothermal field. Science 307, 1428-1434.

Kim, S.-T., O'Neil, J.R., 1997. Equilibrium and nonequilibrium oxygen isotope effects in synthetic carbonates. Geochim. Cosmochim. Acta 61, 3461-3475.

Klein, F., Bach, W., McCollom, T.M., 2013. Compositional controls on hydrogen generation during serpentinization of ultramafic rocks. Lithos 178, 55-69.

Klein, F., Bach, W., Humphris, S.E., Kahl, W.-A., Jöns, N., Moskowitz, B., Berquó, T.S., 2014. Magnetite in seafloor serpentinite-some like it hot. Geology 42, 135-138.

Klein, F., Humphris, S.E., Guo, W., Schubotz, F., Schwarzenbach, E.M., Orsi, W.D., 2015. Fluid mixing and the deep biosphere of a fossil Lost City-type hydrothermal system at the Iberia Margin. Proc. Natl. Acad. Sci. 112, 12036-12041.

Kodolányi, J., Pettke, T., Spandler, C., Kamber, B.S., Gméling, K., 2011. Geochemistry of ocean floor and fore-arc serpentinites: constraints on the ultramafic input to subduction zones. J. Petrol. (egr058).

Korenaga, J., 2007. Thermal cracking and the deep hydration of oceanic lithosphere: a key to the generation of plate tectonics? J. Geophys. Res. Solid Earth 112, B05408.

Labotka, T., Cole, D., Riciputi, L., 2000. Diffusion of C and O in calcite at $100 \mathrm{MPa}$. Am. Mineral. 85, 488-494.

Lafay, R., Deschamps, F., Schwartz, S., Guillot, S., Godard, M., Debret, B., Nicollet, C., 2013. High-pressure serpentinites, a trap-and-release system controlled by metamorphic conditions: example from the Piedmont zone of the western Alps. Chem. Geol. 343, 38-54.

Lafay, R., Montes-Hernandez, G., Janots, E., Chiriac, R., Findling, N., Toche, F., 2014. Simultaneous precipitation of magnesite and lizardite from hydrothermal alteration of olivine under high carbonate alkalinity. Chem. Geol. 368, 63-75.

Lagabrielle, Y., 1987. Les ophiolites: marqueurs de l'histoire tectonique des domaines océaniques: le cas des Alpes franco-italiennes (Queyras, Piémont): comparaison avec les ophiolites d'Antalya (Turquie) et du Coast Range de Californie.

Lagabrielle, Y., 2009. Mantle exhumation and lithospheric spreading: an historical perspective from investigations in the Oceans and in the Alps-Apennines ophiolites. Boll. Soc. Geol. Ital. 128, 279-293. 
Lagabrielle, Y., Cannat, M., 1990. Alpine Jurassic ophiolites resemble the modern central Atlantic basement. Geology 18, 319-322.

Lagabrielle, Y., Lemoine, M., 1997. Alpine, Corsican and Apennine ophiolites: the slowspreading ridge model. C. R. Acad. Sci. Ser. IIA Earth Planet. Sci. 325, 909-920.

Lagabrielle, Y., Vitale Brovarone, A., Ildefonse, B., 2015. Fossil oceanic core complexes recognized in the blueschist metaophiolites of Western Alps and Corsica. Earth-Sci. Rev. 141, 1-26.

Lavoie, D., Cousineau, P.A., 1995. Ordovician ophicalcites of southern Quebec Appalachians: a proposed early seafloor tectonosedimentary and hydrothermal origin. J. Sediment. Res. 65.

Lemoine, M., 1980. Serpentinites, gabbros and ophicalcites in the Piemont-Ligurian domain of the Western Alps: possible indicators of oceanic fracture zones and of associated serpentinite protrusions in the Jurassic-Cretaceous Tethys. Arch. Sci. 33, $103-115$.

Lemoine, M., Bourbon, M., de Graciansky, P.-C., Letolle, R., 1983. Isotopes du carbone et de l'oxygène de calcaires associés à des ophiolites (Alpes occidentales, Corse, Appennin): indices possibles d'un hydrother $\neg$ malisme océanique téthysien. Rev. Géogr. Phys. Géol. Dyn. 24, 305-314.

Lemoine, M., Tricart, P., Boillot, G., 1987. Ultramafic and gabbroic ocean floor of the Ligurian Tethys (Alps, Corsica, Apennines): in search of a genetic imodel. Geology $15,622-625$.

Lewis, A.D., Smewing, J.D., 1980. The Montgenevre ophiolite (Hautes Alpes, France): meta-morphism and trace-element geochemistry of the volcanic sequence. Chem. Geol. 28, 291-306.

Li, X.-H., Faure, M., Lin, W., Manatschal, G., 2013. New isotopic constraints on age and magma genesis of an embryonic oceanic crust: the Chenaillet Ophiolite in the Western Alps. Lithos 160, 283-291.

Ludwig, K.A., Kelley, D.S., Butterfield, D.A., Nelson, B.K., Früh-Green, G., 2006. Formation and evolution of carbonate chimneys at the Lost City Hydrothermal Field. Geochim. Cosmochim. Acta 70, 3625-3645.

MacLeod, C.J., Searle, R., Murton, B., Casey, J., Mallows, C., Unsworth, S., Achenbach, K., Harris, M., 2009. Life cycle of oceanic core complexes. Earth Planet. Sci. Lett. 287, 333-344.

Manatschal, G., Sauter, D., Karpoff, A.M., Masini, E., Mohn, G., Lagabrielle, Y., 2011. The Chenaillet Ophiolite in the French/Italian Alps: an ancient analogue for an oceanic core complex? Lithos 124, 169-184.

Martin, B., Fyfe, W., 1970. Some experimental and theoretical observations on the kinetics of hydration reactions with particular reference to serpentinization. Chem. Geol. 6, 185-202.

McCaig, A.M., Harris, M., 2012. Hydrothermal circulation and the dike-gabbro transition in the detachment mode of slow seafloor spreading. Geology 40, 367-370.

McCaig, A.M., Cliff, R.A., Escartin, J., Fallick, A.E., MacLeod, C.J., 2007. Oceanic detachment faults focus very large volumes of black smoker fluids. Geology 35, 935-938.

McCaig, A.M., Delacour, A., Fallick, A.E., Castelain, T., FrüH-Green, G.L., 2010. Detachment fault control on hydrothermal circulation systems: interpreting the subsurface beneath the TAG hydrothermal field using the isotopic and geological evolution of oceanic core complexes in the Atlantic. Divers. Hydrothermal Syst. Slow Spreading Ocean Ridges, pp. 207-239.

Mével, C., 2003. Serpentinization of abyssal peridotites at mid-ocean ridges. Compt. Rendus Geosci. 335, 825-852.

Mevel, C., Caby, R., Kienast, J.-R., 1978. Amphibolite facies conditions in the oceanic crust: example of amphibolitized flaser-gabbro and amphibolites from the Chenaillet ophiolite massif (Hautes Alpes, France). Earth Planet. Sci. Lett. 39, 98-108.

Mottl, M.J., 1983. Metabasalts, axial hot springs, and the structure of hydrothermal systems at mid-ocean ridges. Geol. Soc. Am. Bull. 94, 161-180.

Müller, T., Cherniak, D., Watson, E.B., 2012. Interdiffusion of divalent cations in carbonates: experimental measurements and implications for timescales of equilibration and retention of compositional signatures. Geochim. Cosmochim. Acta 84, 90-103.

Normand, C., Williams-Jones, A.E., Martin, R.F., Vali, H., 2002. Hydrothermal alteration of olivine in a flow-through autoclave: nucleation and growth of serpentine phases. Am. Mineral. 87, 1699-1709.

O'Hanley, D.S., 1991. Fault-related phenomena associated with hydration and serpentine recrystallization during serpentinization. Can. Mineral. 29, 21-35.

O'Hanley, D.S., Chernosky, J.V., Wicks, F.J., 1989. The stability of lizardite and chrysotile. Can. Mineral. 27, 483-493.

Okamoto, A., Shimizu, H., 2015. Contrasting fracture patterns induced by volumeincreasing and-decreasing reactions: implications for the progress of metamorphic reactions. Earth Planet. Sci. Lett. 417, 9-18.

Paulick, H., Bach, W., Godard, M., De Hoog, J., Suhr, G., Harvey, J., 2006. Geochemistry of abyssal peridotites (Mid-Atlantic Ridge, $1520^{\prime}$ N, ODP Leg 209): implications for fluid/rock interaction in slow spreading environments. Chem. Geol. 234, 179-210.

Pentecost, A., 1995. Geochemistry of carbon dioxide in six travertine-depositing waters of Italy. J. Hydrol. 167, 263-278.

Petersen, S., Kuhn, K., Kuhn, T., Augustin, N., Hékinian, R., Franz, L., Borowski, C., 2009. The geological setting of the ultramafic-hosted Logatchev hydrothermal field $\left(1445^{\prime} \mathrm{N}\right.$, Mid-Atlantic Ridge) and its influence on massive sulfide formation. Lithos 112, 40-56.

Picazo, S., Müntener, O., Manatschal, G., Bauville, A., Karner, G., Johnson, C., 2016. Mapping the nature of mantle domains in Western and Central Europe based on clinopyroxene and spinel chemistry: evidence for mantle modification during an extensional cycle. Lithos 266, 233-263.
Plummer, L.N., Busenberg, E., 1982. The solubilities of calcite, aragonite and vaterite in $\mathrm{CO} 2-\mathrm{H} 2 \mathrm{O}$ solutions between 0 and $90 \mathrm{C}$, and an evaluation of the aqueous mode for the system CaCO3-CO2-H2O. Geochim. Cosmochim. Acta 46, 1011-1040.

Plümper, O., Røyne, A., Magrasó, A., Jamtveit, B., 2012. The interface-scale mechanism of reaction-induced fracturing during serpentinization. Geology 40, 1103-1106.

Putnis, A., Putnis, C.V., 2007. The mechanism of reequilibration of solids in the presence of a fluid phase. J. Solid State Chem. 180, 1783-1786.

Rampone, E., Hofmann, A., Piccardo, G., Vannucci, R., Bottazzi, P., Ottolini, L., 1996. Trace element and isotope geochemistry of depleted peridotites from an N-MORB type ophiolite (Internal Liguride, N. Italy). Contrib. Mineral. Petrol. 123, 61-76.

Roselle, G.T., Baumgartner, L.P., 1995. Experimental determination of anorthite solubility and calcium speciation in supercritical chloride solutions at $2 \mathrm{~kb}$ from 400 to $600 \mathrm{C}$. Geochim. Cosmochim. Acta 59, 1539-1549.

Rouméjon, S., Cannat, M., 2014. Serpentinization of mantle-derived peridotites at midocean ridges: mesh texture development in the context of tectonic exhumation. Geochem. Geophys. Geosyst.

Rouméjon, S., Cannat, M., Agrinier, P., Godard, M., Andreani, M., 2015. Serpentinization and fluid pathways in tectonically exhumed peridotites from the Southwest Indian Ridge (62-65 E). J. Petrol. 56, 703-734.

Rudge, J.F., Kelemen, P.B., Spiegelman, M., 2010. A simple model of reaction-induced cracking applied to serpentinization and carbonation of peridotite. Earth Planet. Sci. Lett. 291, 215-227.

Saccocia, P.J., Seewald, J.S., Shanks, W.C., 2009. Oxygen and hydrogen isotope fractionation in serpentine-water and talc-water systems from 250 to $450{ }^{\circ} \mathrm{C}, 50 \mathrm{MPa}$. Geochim. Cosmochim. Acta 73, 6789-6804.

Schrenk, M.O., Kelley, D.S., Bolton, S.A., Baross, J.A., 2004. Low archaeal diversity linked to subseafloor geochemical processes at the Lost City Hydrothermal Field, Mid-Atlantic Ridge. Environ. Microbiol. 6, 1086-1095.

Schroeder, T., John, B., Frost, B.R., 2002. Geologic implications of seawater circulation through peridotite exposed at slow-spreading mid-ocean ridges. Geology 30, 367-370.

Schwartz, S., Lardeaux, J.M., Tricart, P., Guillot, S., Labrin, E., 2007. Diachronous exhumation of HP-LT metamorphic rocks from south-western Alps: evidence from fission-track analysis. Terra Nova 19, 133-140.

Schwartz, S., Guillot, S., Reynard, B., Lafay, R., Debret, B., Nicollet, C., Lanari, P., Auzende A.L., 2013. Pressure-temperature estimates of the lizardite/antigorite transition in high pressure serpentinites. Lithos 178, 197-210.

Schwarzenbach, E.M., Früh-Green, G.L., Bernasconi, S.M., Alt, J.C., Plas, A., 2013. Serpentinization and carbon sequestration: a study of two ancient peridotitehosted hydrothermal systems. Chem. Geol. 351, 115-133.

Sheppard, S.M., 1980. Isotopic Evidence for the Origins of Water During Metamorphic Processes in Oceanic Crust and Ophiolite Complexes. Presented at the Colloq. Int. CNRS. pp. 135-147.

Simmons, S.F., Christenson, B.W., 1994. Origins of calcite in a boiling geothermal system. Am. J. Sci. 294, 361-400.

Spötl, C., Vennemann, T.W., 2003. Continuous-flow isotope ratio mass spectrometric analysis of carbonate minerals. Rapid Commun. Mass Spectrom. 17, 1004-1006.

Sverjensky, D.A., Shock, E.L., Helgeson, H.C., 1997. Prediction of the thermodynamic properties of aqueous metal complexes to $1000{ }^{\circ} \mathrm{C}$ and $5 \mathrm{~kb}$. Geochim. Cosmochim. Acta $61,1359-1412$.

Treves, B.E., Harper, G.D., 1994. Exposure of serpentinites on the ocean floor: sequence of faulting and hydrofracturing in the Northern Apennine ophicalcites. Ofioliti 19, 435-466.

Tricart, P., Schwartz, S., 2006. A north-south section across the Queyras Schistes lustrés (Piedmont zone, Western Alps): syn-collision refolding of a subduction wedge. Eclogae Geol. Helv. 99, 429-442.

Trommsdorff, V., Evans, B.W., Pfeifer, H., 1980. Ophicarbonate rocks: metamorphic reactions and possible origin. Arch. Sci. Geneve 33, 3610364

Tucholke, B.E., Lin, J., 1994. A geological model for the structure of ridge segments in slow spreading ocean crust. J. Geophys. Res. 99, 11937-11958.

Tucholke, B.E., Humphris, S.E., Dick, H.J., 2013. Cemented mounds and hydrotherma sediments on the detachment surface at Kane Megamullion: a new manifestation of hydrothermal venting. Geochem. Geophys. Geosyst. 14, 3352-3378.

Urai, J.L., Williams, P.F., van Roermund, H.L.M., 1991. Kinematics of crystal growth in syntectonic fibrous veins. J. Struct. Geol. 13, 823-836.

Vils, F., Pelletier, L., Kalt, A., Müntener, O., Ludwig, T., 2008. The Lithium, Boron and Beryllium content of serpentinized peridotites from ODP Leg 209 (Sites 1272A and 1274A): implications for lithium and boron budgets of oceanic lithosphere. Geochim. Cosmochim. Acta 72, 5475-5504.

Weissert, H., Bernoulli, D., 1984. Oxygen isotope composition of calcite in Alpine ophicarbonates: a hydrothermal or Alpine metamorphic signal? Eclogae Geol. Helv. 77, 29-43.

Wicks, F., Whittaker, E., 1977. Serpentine textures and serpentinization. Can. Mineral. 15 459-488.

Wicks, F., Zussman, J., 1975. Microbeam X-ray diffraction patterns of the serpentine minerals. Can. Mineral. 13, 244-258.

Zheng, Y.-F., 1990. Carbon oxygen isotopic covariation in hydrothermal calcite during degassing of CO2. Mineral. Deposita 25, 246-250.

Zheng, Y.-F., 1993. Calculation of oxygen isotope fractionation in hydroxyl-bearing silicates. Earth Planet. Sci. Lett. 120 (3-4), 247-263. 